\title{
Zinc Affects Differently Growth, Photosynthesis, Antioxidant Enzyme Activities and Phytochelatin Synthase Expression of Four Marine Diatoms
}

\author{
Thi Le Nhung Nguyen-Deroche, ${ }^{1}$ Aurore Caruso, ${ }^{1}$ Thi Trung Le,, Trang Viet Bui, ${ }^{3}$ \\ Benoît Schoefs, ${ }^{1}$ Gérard Tremblin, ${ }^{1}$ and Annick Morant-Manceau ${ }^{1}$ \\ ${ }^{1}$ Mer, Molécules, Santé, EA 2160, LUNAM Université, Faculté des Sciences et Techniques, Université du Maine, \\ Avenue Olivier Messiaen, 72085 Le Mans cedex 9, France \\ ${ }^{2}$ Laboratory of Plant Physiology, Department of Biology, University of Education of Ho Chi Minh City, 5th District, \\ 280 An Duong Vuong, Ho Chi Minh City, Vietnam \\ ${ }^{3}$ Plant Physiology Department, Faculty of Biology, University of Natural Sciences, 227 Nguyen Van Cu, 5th District, \\ Ho Chi Minh City, Vietnam
}

Correspondence should be addressed to Annick Morant-Manceau, annick.manceau@univ-lemans.fr

Received 28 October 2011; Accepted 10 January 2012

Academic Editor: Mahir D. Mamedov

Copyright (C) 2012 Thi Le Nhung Nguyen-Deroche et al. This is an open access article distributed under the Creative Commons Attribution License, which permits unrestricted use, distribution, and reproduction in any medium, provided the original work is properly cited.

\begin{abstract}
Zinc-supplementation $(20 \mu \mathrm{M})$ effects on growth, photosynthesis, antioxidant enzyme activities (superoxide dismutase, ascorbate peroxidase, catalase), and the expression of phytochelatin synthase gene were investigated in four marine diatoms (Amphora acutiuscula, Nitzschia palea, Amphora coffeaeformis and Entomoneis paludosa). Zn-supplementation reduced the maximum cell density. A linear relationship was found between the evolution of gross photosynthesis and total chlorophyll content. The $\mathrm{Zn}$ treatment decreased the electron transport rate except in A. coffeaeformis and in E. paludosa at high irradiance. A linear relationship was found between the efficiency of light to evolve oxygen and the size of the light-harvesting antenna. The external carbonic anhydrase activity was stimulated in Zn-supplemented E. paludosa but was not correlated with an increase of photosynthesis. The total activity of the antioxidant enzymes did not display any clear increase except in ascorbate peroxidase activity in $N$. palea. The phytochelatin synthase gene was identified in the four diatoms, but its expression was only revealed in N. palea, without a clear difference between control and $\mathrm{Zn}$-supplemented cells. Among the four species, A. paludosa was the most sensitive and $A$. coffeaeformis, the most tolerant. A. acutiuscula seemed to be under metal starvation, whereas, to survive, only N. palea developed several stress responses.
\end{abstract}

\section{Introduction}

Marine diatoms fulfill important roles in the biosphere. Among these, diatoms are responsible for about $25 \%$ of annual inorganic carbon fixation in oceans [1]. This $\mathrm{CO}_{2}$ is fixed through the photosynthetic process into energy-rich molecules that ultimately serve to feed the other levels of the trophic networks. To fulfill this role, diatoms as other living organisms must find in their environment good conditions, including the right range of macro- and microelements. Among the mandatory microelements required for cell functioning, zinc $(\mathrm{Zn})$ occupies a particular place because it acts as a structural component [2] and as functional component of numerous enzymes, in some gene transcription regulators [3] and as a cofactor in zinc-finger protein involved in mitosis regulation [4] (for review, see [5]). As for other nutrient, $\mathrm{Zn}$ should be present within a definite range to allow optimum cell functioning and growth. In Zn-deficient conditions, diatoms cannot develop whereas when $\mathrm{Zn}$ is present in excess, crucial processes are inhibited partially or totally (growth: [6-8], photosynthesis: $[9,10]$ ) while the oxidative stress develops [11-13]. Because the optimal range of $\mathrm{Zn}$ concentrations depends on diatom species, this type of algae is used as bioindicators [14].

Physiological and biochemical studies have demonstrated that the capacity to tolerate $\mathrm{Zn}$ is linked to the ability 
to establish defense mechanisms (for reviews see $[5,15]$ ). Among these mechanisms, $\mathrm{Zn}$ chelation seems to be major. $\mathrm{Zn}$ ions can be chelated by exopolysaccharides as in the diatom Skeletonema costatum [16] or in the cytoplasm by phytochelatins, which are cysteine-rich pseudopeptides. Phytochelatins are synthesized by addition of glutathione units $(\gamma$ Glu-Cys-Gly) through the catalytic action of phytochela-tin synthase (PCS), a $\gamma$-glutamyl cysteine transpeptidase [17].

The aim of this study was to compare the effect of an increase of $\mathrm{Zn}$ ion concentration on the growth, photosynthetic process, and responses to metal stress of four diatom species. Amphora acutiuscula and Nitzschia palea were harvested and isolated from the South-East Vietnamese coast, at the Can Gio site, which is confronted by pollution from the Mekong River, and two other diatom species (A. coffeaeformis and Entomoneis paludosa) isolated from the French Atlantic coast. N. palea often develops in polluted waters [18], and $A$. coffeaeformis has been shown to be a tolerant species to UV $[19,20]$ and $\mathrm{Cu}[10]$ but sensitive to $\mathrm{Cd}[14]$.

\section{Materials and Methods}

2.1. Culture Conditions. Amphora acutiuscula Kützing and Nitzschia palea (Kützing) Smith were collected at the Can Gio coastal site in South East Vietnam (latitude: $10^{\circ} 40^{\prime} 09^{\prime \prime}$; longitude: $107^{\circ} 00^{\prime} 59^{\prime \prime}$ ), whereas A. coffeaeformis (Agardh) Kützing and Entomoneis paludosa (W. Smith) Reimer were collected on the French Atlantic coast and were obtained from the Nantes Culture Collection (strains UTC58 and NCC18.2, resp.). Each taxon was axenically cultured in artificial seawater (ASW) prepared from Millipore ultrapure water according to Harrison et al. [21]. Diatoms originating from the Vietnamese coast and from the French coast were maintained at $23^{\circ} \mathrm{C}$ and $16^{\circ} \mathrm{C}$, respectively. The cultures were illuminated using cool-white fluorescent tubes (at a photon flux density of $300 \mu \mathrm{mol}$ photons $\mathrm{PAR} \mathrm{m}^{-2} \mathrm{~s}^{-1}$, Philips TLD, $18 \mathrm{~W})$ under a light-dark (14/10 h) cycles. The photon flux density was measured using a $4 \pi$ waterproof light probe (Walz, Germany) connected to a Li-Cor 189 quantum meter. The growth temperatures were maintained for measurements. For experiments, exponentially growing cells were harvested from precultures, centrifuged gently $\left(900 \times \mathrm{g}, 10 \mathrm{~min}, 4^{\circ} \mathrm{C}\right)$ and inoculated sterilely into fresh ASW supplemented or not with a sterile $\mathrm{ZnCl}_{2}$ stock solution. The final $\mathrm{Zn}$ concentration was $20 \mu \mathrm{M}$. The $\mathrm{Zn}$ concentration of fresh ASW was $0.25 \mu \mathrm{M}$. The cultures were performed in Erlenmeyer flasks of $250 \mathrm{~mL}$ capacity that were inoculated at a cell density of $10^{4}$ cells $\mathrm{mL}^{-1}$. This concentration was chosen after preliminary trials showing that this $\mathrm{Zn}$ concentration was the highest $\mathrm{Zn}$ concentration tolerated by all four diatoms for at least 10 days (results not shown). All the measurements were performed with cells from cultures at the exponential growth phase that is 5 days from inoculation (data not shown).

2.2. Algal Growth and Chlorophyll $a$ and $c$ Contents. Growth in the cultures was monitored by daily cell counts using a
Neubauer type hemacytometer. The growth rate was calculated during the exponential phase, and the maximum cell density was determined from the stationary phase of the growth curves. Chlorophyll $(\mathrm{Chl}) a$ and $\mathrm{Chl} c$ were measured spectrophotometrically according to Speziale et al. [22].

\subsection{Oxygen Evolution and Chlorophyll Fluorescence Measure-} ments. Oxygen evolution was determined using a thermostated chamber equipped with a Clark-type oxygen electrode (DW2, Hansatech Instruments Ltd., UK). The oxygen evolution was measured under actinic irradiance ranging from 0 to $1200 \mu \mathrm{mol}$ photons PAR $\mathrm{m}^{-2} \mathrm{~s}^{-1}$. The gross photosynthesis was calculated as the net photosynthesis plus respiration, assuming that the respiration rate was constant in light and in darkness. The gross photosynthesis versus irradiance curves ( $P$ versus $E$ curves) were fitted according to the model of Eilers and Peeters [23] using the Sigma-plot software.

Chl fluorescence was measured using a FMS1 modulated fluorometer (Hansatech Ltd., UK) modified to make it suitable for use at low Chl $a$ concentrations [24]. To obtain the relative electron transport rate versus irradiance (rETR versus $E$ ) curves, algae were submitted to 11 levels of actinic light progressing from 0 to $1200 \mu \mathrm{mol}$ photons PAR m $\mathrm{m}^{-2} \mathrm{~s}^{-1}$. The fitting of experimental data to rETR versus $E$ curves were calculated as indicated by Eilers and Peeters [23] and Mouget et al. [25].

2.4. Carbonic Anhydrase Activity. The carbonic anhydrase (CA) activity was measured according to Dionisio-Sese and Miyachi [26] and Morant-Manceau et al. [27]. Intact cells were used to quantify the extracellular CA activity $\left(\mathrm{CA}_{\text {ext }}\right)$, while the total CA activity was quantified using cells homogenized in liquid nitrogen $\left(\mathrm{CA}_{\text {tot }}\right)$. The internal CA activity $\left(\mathrm{CA}_{\text {int }}\right)$ was calculated as $\mathrm{CA}_{\text {tot }}$ activity minus $\mathrm{CA}_{\mathrm{ext}}$ activity.

2.5. Antioxidant Enzymatic Activities. The algae were harvested by centrifugation $\left(900 \times \mathrm{g}, 4^{\circ} \mathrm{C}\right)$ and ground in a liquid nitrogen frozen potassium phosphate buffer $\left(\mathrm{K}_{2} \mathrm{HPO}_{4}\right.$ $50 \mathrm{mM}$, EDTA Na $1 \mathrm{mM}, \mathrm{pH} 7$ ) using a mortar and a pestle. The homogenate was centrifuged $\left(10,000 \times \mathrm{g}, 15 \mathrm{~min}, 4^{\circ} \mathrm{C}\right)$, and the supernatant was used for spectrophotometric determination of enzymatic activity. Catalase (CAT) activity was estimated by tracking the reduction of $\mathrm{H}_{2} \mathrm{O}_{2}$ at $240 \mathrm{~nm}$ and $20^{\circ} \mathrm{C}$ [28]. The reaction mixture contained $200 \mu \mathrm{M} \mathrm{H}_{2} \mathrm{O}_{2}$ in $50 \mathrm{mM}$ of pH 7.5 potassium phosphate buffer. Ascorbate peroxidase (APX) activity was evaluated by tracking the changes in absorbance at $290 \mathrm{~nm}$ of the ascorbate substrate in a reaction mixture composed of ascorbate $10 \mathrm{mM}$ and $\mathrm{H}_{2} \mathrm{O}_{2}$ $10 \mathrm{mM}$ in $50 \mathrm{mM}$ of $\mathrm{pH} 7.0$ potassium phosphate buffer. Ascorbate oxidation was measured at $25^{\circ} \mathrm{C}$ [29]. One unit of enzymatic activity (CAT and APX) was defined as the amount of enzymes that catalyses the conversion of one $\mu$ mole of substrate per $\min$ [30]. Superoxide dismutase (SOD) activity was determined by measuring the inhibition of photochemical reduction of nitroblue tetrazolium (NBT), which absorbs at $560 \mathrm{~nm}$. One unit of SOD activity was calculated as the amount required to cause $50 \%$ inhibition of 
the photoreduction of NBT [31]. Protein concentration of diatom extracts was determined by standardizing versus bovine serum albumin, according to Hartree [32].

2.6. Extraction of Nucleic Acids, PCR Amplification, and Bacterial Transformation. DNA was extracted from about $1 \mathrm{~g}$ of fresh tissues as described by J. J. Doyle and J. L. Doyle [33] after grinding in liquid nitrogen. The samples were dissolved in $80 \mu \mathrm{L}$ water. Partial genomic DNA sequences of phytochelatin synthase were obtained by the following PCR procedure. Primer sequences FPCdia/RPCdia ( $5^{\prime}$-ATGGAARGGACCATGGAGRTG- $3^{\prime}$ and $5^{\prime}$-ATRGGWGAAAAATGYCCMGTTCC- $3^{\prime}$ ) and nested primer sequences NFPCdia/NRPCdia (5' -ACCATGGAGRTGGTAYGARGA- $3^{\prime}$ and $5^{\prime}$-TTCCAGTTTGMCC- $3^{\prime}$ ) corresponding to conserved sequences were designated from the alignment of PCS nucleic acid sequences of both model diatoms: Thalassiosira pseudonana and P. tricornutum (http://genome.jgi-psf.org/). Thirty cycles consisting of denaturing for $30 \mathrm{~s}$ at $94^{\circ} \mathrm{C}$, annealing for $1 \mathrm{~min}$ at $57.2^{\circ} \mathrm{C}$, and extension for $2 \mathrm{~min}$ at $72^{\circ} \mathrm{C}$ were performed. The reaction was completed by an extension step at $72^{\circ} \mathrm{C}$. The first PCR was performed with $0.2 \mu \mathrm{M}$ of FPCdia, $0.2 \mu \mathrm{M}$ of RPCdia, and 2.5 units of Thermus aquaticus (Taq) DNA polymerase (Promega). Amplified DNA products were subjected to a second PCR with nested primers using the same conditions, apart from a slightly higher annealing temperature $\left(57.5^{\circ} \mathrm{C}\right)$. PCR products were cloned into pGEMTEasy vector (Promega) containing a cassette conferring the resistance to ampicillin. The ligation productions were transformed into Escherichia coli DH5 $\alpha$. Recombinant bacteria were selected and sequenced on both strands (Operon, Deutschland). Total RNAs (control and sample with $\mathrm{Zn}$ $20 \mu \mathrm{M}$ ) were extracted using the RNeasy Plant Mini Kit (Qiagen, MD, USA), and stored at $-80^{\circ} \mathrm{C}$ before northern blot analysis.

2.7. Sequence Analysis. The sequences obtained after PCR were subjected to a homology search through the BLAST program available at the NCBI GenBank biocomputing site (http://blast.ncbi.nlm.nih.gov) [34]. The deduced amino acid sequences were obtained using the translate software available at the server: (http://www.bioinformatics.org/ sms/index.html). The multiple alignments of the sequenced fragments were carried out using the ClustalW EBI program and visualized using Genedoc, version 2.6 [35].

2.8. Northern Blot Analysis. Equal amounts $(7.5 \mu \mathrm{g})$ of total RNA samples were denatured and fractionated by electrophoresis in 1.2\% agarose denaturing gel [36]. Total RNA quality was confirmed by ribosomal RNA integrity observed after agarose gel ethidium bromide treatment [36]. Gels were blotted by a capillary procedure [36] on NY Plus membrane (Porablot, Macherey-Nagel, Düren, Germany). Fractionated RNAs were crosslinked at $80^{\circ} \mathrm{C}$. The membrane was stained with methylene blue to check the ribosomal RNA quality. The radiolabeled PCS probe was obtained by using the Prime a Gene Labeling System kit (Promega, Madisson, WI, USA) with the cloned cDNA adding $50 \mu \mathrm{Ci}(330 \mathrm{nM})$ of $\left[\alpha^{32} \mathrm{P}\right] \mathrm{dCTP}$. The probe was purified on G50 microcolumns (Amersham-Pharmacia, Orsay, France). Membranes were prehybridized in a hybridization buffer [36] for $2 \mathrm{~h}$, and then $\left[\alpha^{32} \mathrm{P}\right] \mathrm{dCTP}$ radiolabeled probes $1 \times 1010 \mathrm{cpm} \mu \mathrm{g}^{-1}$ were added. Membranes were exposed to X-ray film (Kodak) for $12 \mathrm{~h}$ at $-70^{\circ} \mathrm{C}$. These experiments were duplicated.

2.9. Statistical Analysis. We used a one-way analysis of variance (ANOVA) to determine the statistical significance of differences in all experiments. To be statistically significant, a difference had to display a level of significance of at least $5 \%$ $(P \leq 0.05)$ using the Tukey test run on SigmaStat version 3.1 software compatible with SigmaPlot 9.0. All measurements were made on 3-5 replicates (from different cultures), and the results were expressed as means and standard errors.

\section{Results and Discussion}

3.1. Effects of Zinc on Growth. In the absence of Zn-supplementation, the highest cell density was reached with $N$. palea, which was also the taxon dividing with the slowest rate (Table 1). The two Amphora taxons behaved similarly, reaching medium cell densities but the highest dividing rate. E. paludosa reached the lowest cell density and the division rate was intermediate between those measured for Amphora $s p$. and $N$. palea (Table 1). These data agree with those published previously on the same Amphora species but not for N. palea and E. paludosa, for which higher values were found by Nguyen-Deroche et al. [10]. The supplementation of the growth medium with $\mathrm{Zn}$ affected differentially the growth of the different taxons. For the four taxons, the maximum cell density decreased, while the growth rate remained constant in the Amphora species, increased in $N$. palea, and dramatically decreased in E. paludosa (Table 1). Altogether, the data suggests that in N. palea, Zn stimulated mitosis for a short period before to inhibit this process, leading to a reduced maximum cell density. In the other taxons, $\mathrm{Zn}$ ions have only negative effects on culture growth. This negative effect has been already observed for lower Zn concentrations in different species such as Nitzschia closterium (0-1.52 $\mu \mathrm{M}$ : [6]), S. costatum (24 pM: [37]), and $P$. tricornutum (0.05-10 $\mu \mathrm{M}$ : [38]).

The results of this experiment allowed us to range both Amphora species as $\mathrm{Zn}$-tolerant taxons and both P. paludosa and $N$. palea as $\mathrm{Zn}$-sensitive taxons. This conclusion fits with the results already published on Zn sensitivity of Nitzschia [6]. Interestingly, these taxons reacted differently when facing to an increase of $\mathrm{Cu}[10]$. Despite the fact that $\mathrm{Zn}$ can be important for mitosis regulation [4], algal growth depends primarily on photosynthesis. Therefore, this process was characterized at the biochemical and physiological level in the four diatom species grown in the presence or in the absence of $\mathrm{Zn}$.

3.2. Effects of Zinc on Chlorophyll Contents. Chl quantifications in the four taxons grown in the absence of the $\mathrm{Zn}$ supplementation revealed that $A$. acutiuscula and E. paludosa contained three times more total $\mathrm{Chl}$ than the two other 


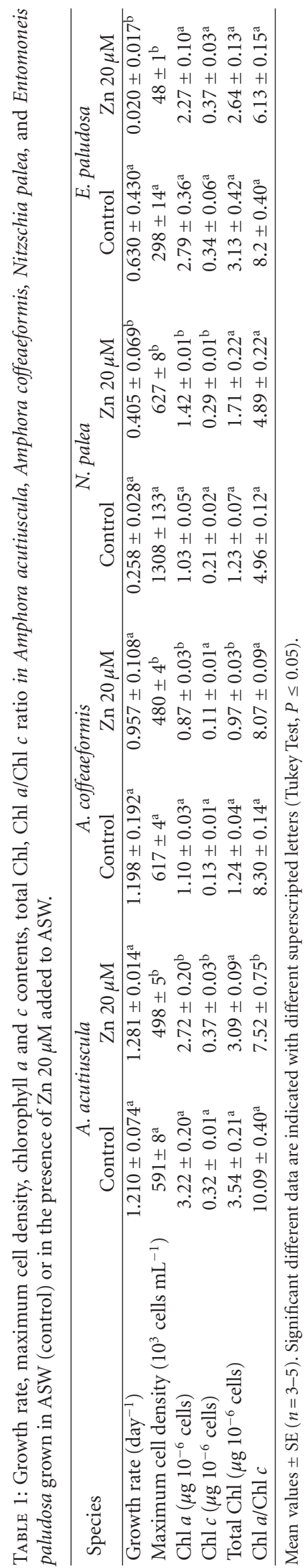


taxons. Chl $a$ was always the major pigment (Table 1). This difference was not reflected in the $\mathrm{Chl} a / \mathrm{Chl} c$ ratio, always higher than 8 , except for $N$. palea for which the ratio was close to 5 . Because the $\mathrm{Chl} a / \mathrm{Chl} c$ ratio constitutes a rough measure of the size of the light-harvesting antenna [39], this result suggests that the antenna of $N$. palea is larger than in the other species. The addition of $\mathrm{Zn}$ did not significantly impact the total Chl amount in A. acutiuscula, whereas it triggered an increase in $N$. palea and a decrease in A. coffeaeformis and E. paludosa. The Chl a/Chl $c$ ratio was not affected in A. acutiuscula and N. palea, whereas it was decreased by at least two units in E. paludosa and A. coffeaeformis (Table 1). Although the different culture protocols used in the literature make difficult the comparison of $\mathrm{Zn}$ effects on Chl contents, it is generally found that metals in excess, including $\mathrm{Zn}$, reduce the $\mathrm{Chl} a$ amount ( $\mathrm{Zn}$ Chlorella vulgaris: [40]; Zn-Pavlova viridis: [11]; Cd, Cumultispecies: [41]) with a notable exception in the diatom Asterionella japonica for which an increase was reported [42]. The way used by $\mathrm{Zn}$ to impact the Chl amount is not clear and no reasonable hypothesis can be proposed at the present state of our knowledge. Regardless of this reason, it is worse to mention that the $\mathrm{Chl} a / \mathrm{Chl} c$ ratio remained stable while in green algae, the ratio $\mathrm{Chl} a / \mathrm{Chl} b$ decreases due to the inhibition of Chl $b$ formation from Chl $a[43,44]$. Because Chl $c$ derived from the Chl precursor protochlorophyllide (reviewed in [45]), any block or stimulation of the biochemical steps prior protochlorophyllide formation would affect similarly the amount of both pigment types leading the ratio to remain unchanged. Altogether, the results suggest that the $\mathrm{Zn}$ excess does not modify the size of the light-harvesting complexes except in E. paludosa and in A. acutiuscula. In the two other species, the increase in total $\mathrm{Chl}$ content would speak in favor of a $\mathrm{Zn}$-induced increase of the number of photosynthetic chains. In order to test this hypothesis, we measured the variation of the gross photosynthesis and of the relative electron transfer rate versus the irradiance level.

3.3. Effects of Zinc on Photosynthesis. In the absence of Znsupplementation, the curves $P / E$ presented the same trends. Both increased and saturated between $600-800 \mu \mathrm{mol}$ photons PAR $\mathrm{m}^{-2} \mathrm{~s}^{-1}$ (Figure 1). However, the maximum amplitude reached was different for the different species (Table 2). The $\mathrm{Zn}$-supplementation affected negatively the gross photosynthesis in E. paludosa and N. palea but positively that of both Amphora species (Figure 1), confirming that these species are better in managing the excess of zinc. A decrease in photosynthetic activity has also been observed in other microalgae at various $\mathrm{Zn}$ concentrations ( $S$. costatum$>24$ pM: [37]; Chlamydomonas reinhardtii-30.8 $\mu \mathrm{M}$ : [46]; Pseudokirchneriella subcapitata-14 $\mu \mathrm{M}$ : [47]).

The impairment of photosynthesis is reflected in the values of the parameters characterizing $P / E$ curves (Table 2).

The $\alpha^{B}$ Parameter. It reflects the affinity of the algae for light. In the absence of $\mathrm{Zn}$-supplementation, $\alpha^{B}$ ranged between 2.2-2.3 for the Amphora species to 3.0-3.7 for the two other species. These values were higher in the presence of the Zn-supplementation except in E. paludosa for which it decreased. For the same photon flux density, the speed at which $\mathrm{O}_{2}$ is evolved is primarily dependent on the size of the light harvesting complex, which is reflected in the Chl $a / \mathrm{Chl} c$ ratio. Therefore, a linear relationship between the two parameters should be observed. To test this hypothesis, the $\alpha^{B}$ values were plotted against the Chla/Chlc values obtained with diatoms grown in the presence of an excess of $\mathrm{Zn}$ (Figure 2(a)). The linear relationship obtained suggests the validity of the hypothesis.

The $P_{\max }^{B}$ Parameter. This factor reflects the photosynthetic activity when the light is saturating. In the absence of $\mathrm{Zn}$ supplementation, the values of $P_{\max }^{B}$ were high except for A. acutiuscula for which the value was reduced by 50 to $75 \%$ (Table 2). $P_{\max }^{B}$ was increased in both Amphora species, but was lower in the other two diatoms in comparison to controls. The maximum oxygen evolved is primarily related to the total Chl present and therefore a linear relationship should be found when the $P_{\max }^{B}$ values are plotted against the total Chl amount. This linear relationship was indeed found (Figure 2(b)).

The Parameter $E_{k}$. It reflects the photon flux density from which the photosynthetic activity does not increase proportionally to the light intensity. In the absence of $\mathrm{Zn}$ supplementation, the values of $E_{k}$ for A. acutiuscula and E. paludosa were lower than those obtained for the two other species suggesting that the two former species are more sensitive to high-light than the others. This is also reflected by the lower value of $P_{\max }^{B}$ for these two species. The $\mathrm{Zn}$ supplementation did not change significantly the $E_{k}$ levels (Table 2).

The $P / E$ curves give information on how $\mathrm{Zn}$ affects the PSII functioning. In order to enlarge our picture on the impact of $\mathrm{Zn}$ on the photosynthetic process, we followed the response of the relative electron transport rate (rETR) to increasing photon flux density. In the absence of Znsupplementation, the curves $\mathrm{rETR} / E$ presented the same trends as the $P / E$ curves except that they never completely saturated. $\mathrm{rETR}_{\max }$ reached were similar among the different species (around 40) except for N. palea, which reached 80 (Figure 3). The Zn-supplementation affected negatively the rETR in $E$. paludosa and $N$. palea, suggesting that $\mathrm{Zn}$ might have several targets. To get more information from the curves, the characteristic parameters were calculated (Table 2).

The $\alpha_{\text {rETR }}$ Parameter. It reflects the efficiency of the algae to use the incoming light to drive the electron transport. In the absence of $\mathrm{Zn}$-supplementation, the taxons were equally performant in using the incoming light except $A$. acutiuscula, which was the less efficient. In N. palea and A. coffeaeformis, $\alpha_{\mathrm{rETR}}$ was not modified, whereas it was considerably higher in A. acutiuscula (+95\%) and lower in E. paludosa (-40\%).

The $r E T R_{\max }$ Parameter. This factor reflects the maximum ETR when the light is saturating. In the absence of $\mathrm{Zn}$ supplementation, the taxons reached the same value for this parameter except $N$. palea, which exhibited a much higher 


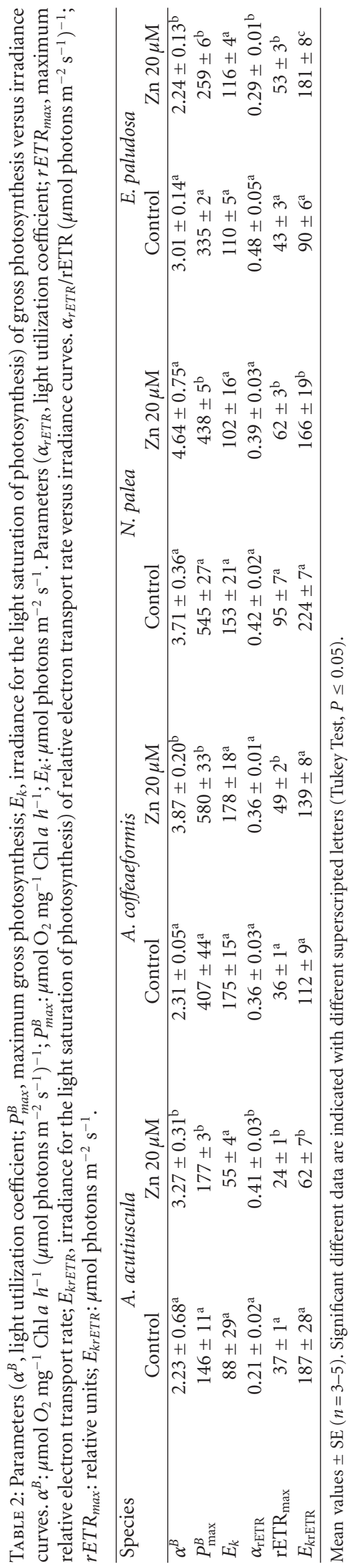




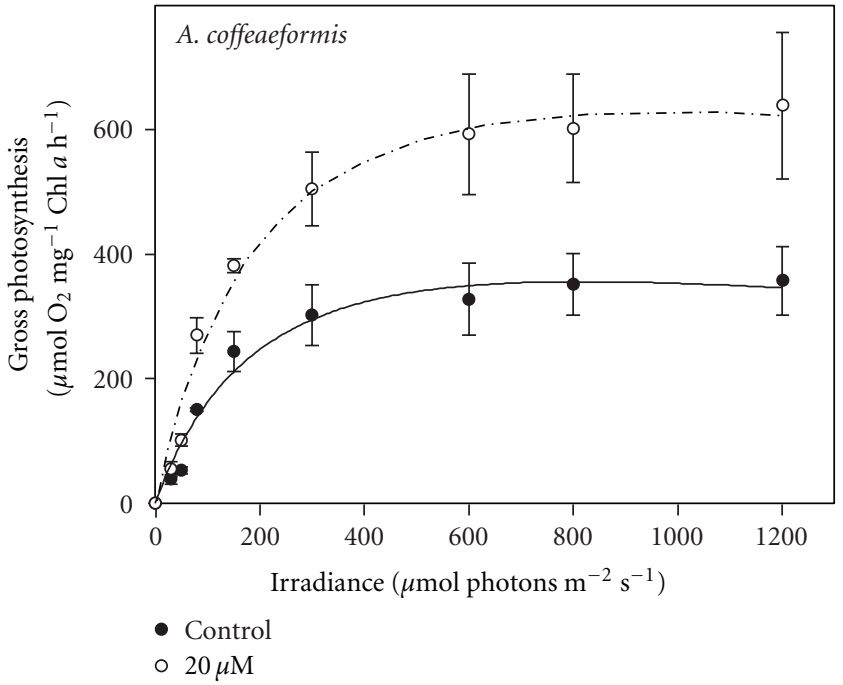

(a)

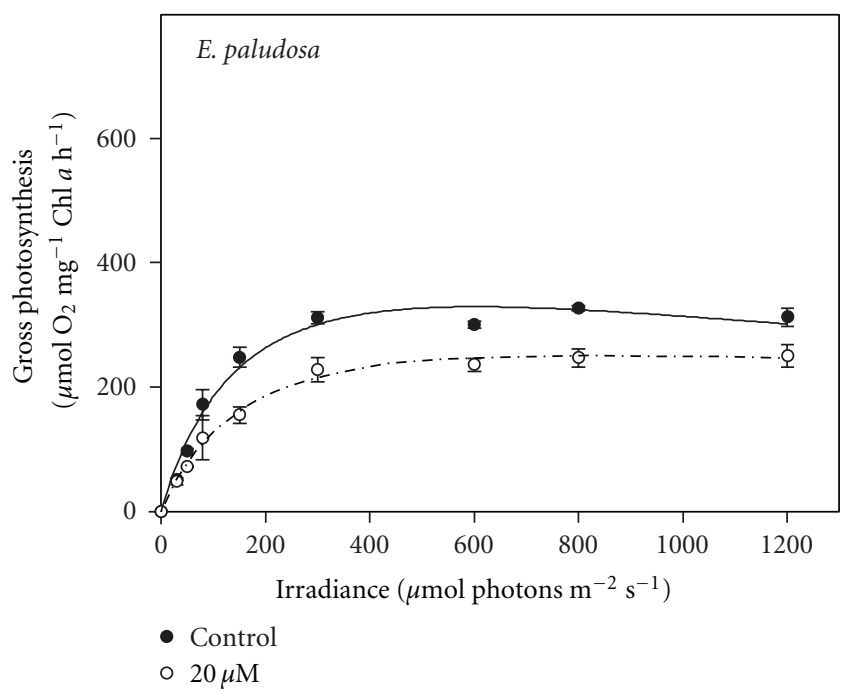

(c)

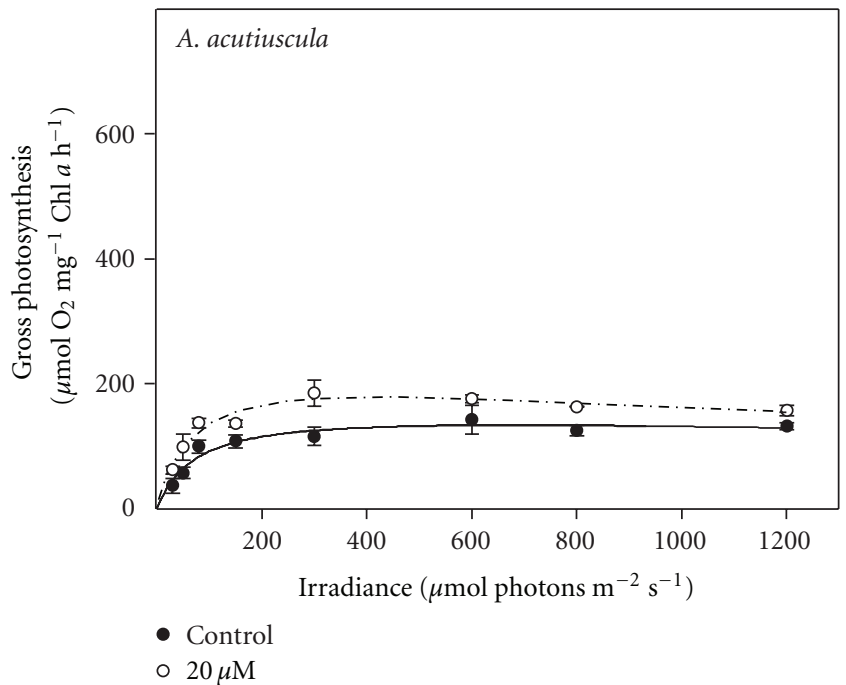

(b)

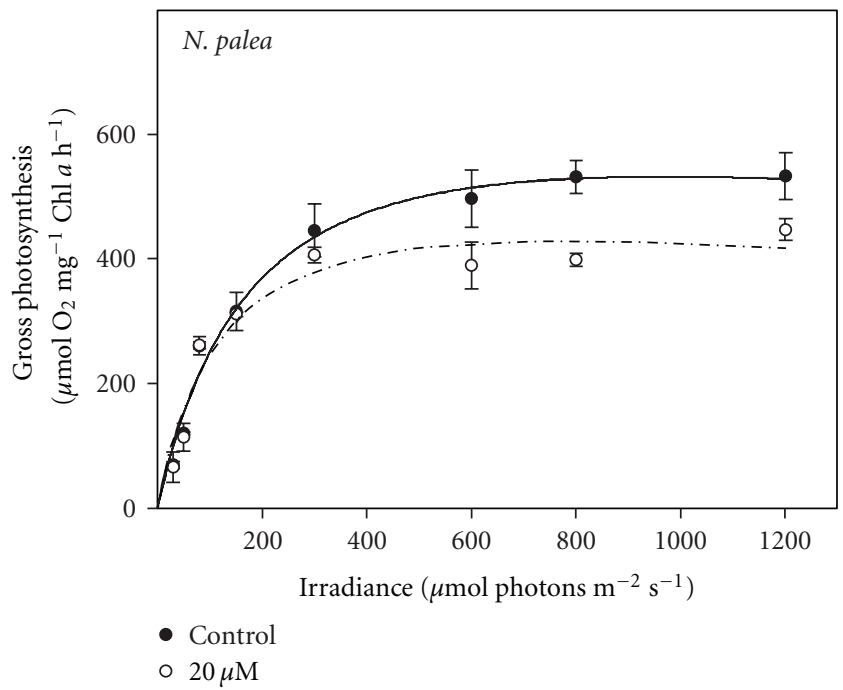

(d)

FIGURE 1: Gross photosynthesis versus irradiance curves in Amphora coffeaeformis, Amphora acutiuscula, Entomoneis paludosa, and Nitzschia palea grown in ASW (control) or in the presence of $20 \mu \mathrm{M} \mathrm{Zn}$ added to ASW. Mean values \pm SE $(n=3-5)$.

level at saturation. In the presence of $\mathrm{Zn}$ excess, the intensity of this parameter significantly increased in A. coffeaeformis and E. paludosa, whereas it significantly decreased in the two other species.

The $E_{\text {krETR }}$ parameter. It reflects the photon flux density from which the ETR does not increase proportionally to the light intensity. E. paludosa and A. coffeaeformis presented lower values than for the two other species. The values of this parameter were reduced in $N$. palea and A. acutiuscula, but considerably increased in E. paludosa (+107\%) (Table 2).

$P / E$ and $\mathrm{rETR} / E$ are two ways to measure the photosynthetic activity [48]. Therefore, from the theoretical point of view, both parameters vary in the same way [49] as shown in the case of A. coffeaeformis in the absence or in the presence of $\mathrm{Zn}$ supplementation (Figure 4). However, a stress may affect differentially the PSII and the electron transport chain and disrupts the linear relationship between these two parameters. This is obviously the case in A. acutiuscula (Figure 4), in which the absence of $\mathrm{Zn}$ made the electron rate slower than the oxygen evolution rate. The Zn supplementation restored the proportionality between the two activities. This result suggests that in the ASW used here, $A$. acutiuscula underwent a slight $\mathrm{Zn}$ deprivation. This slight $\mathrm{Zn}$ deprivation would also affect $A$. coffeaeformis because both parameters were most intense in the presence of $\mathrm{Zn}$ (Figures 1 and 3$)$.

In the absence of $\mathrm{Zn}$, the electron transport rate was faster than the oxygen evolution rate in E. paludosa. Such a 


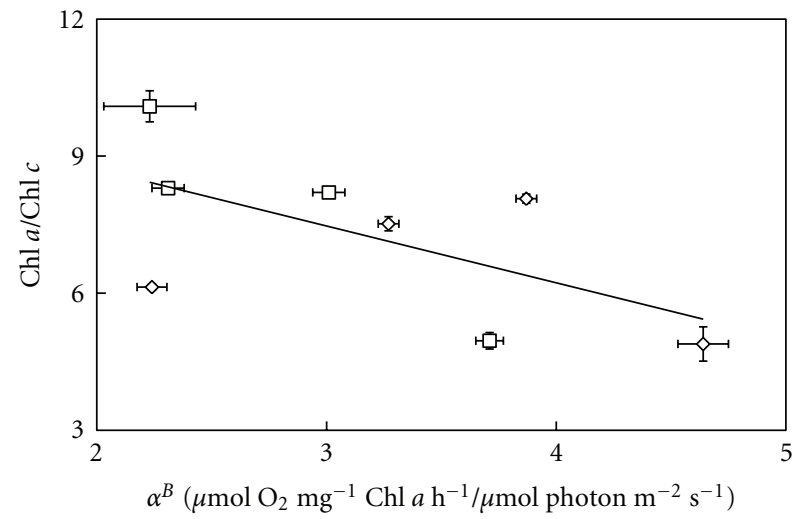

(a)

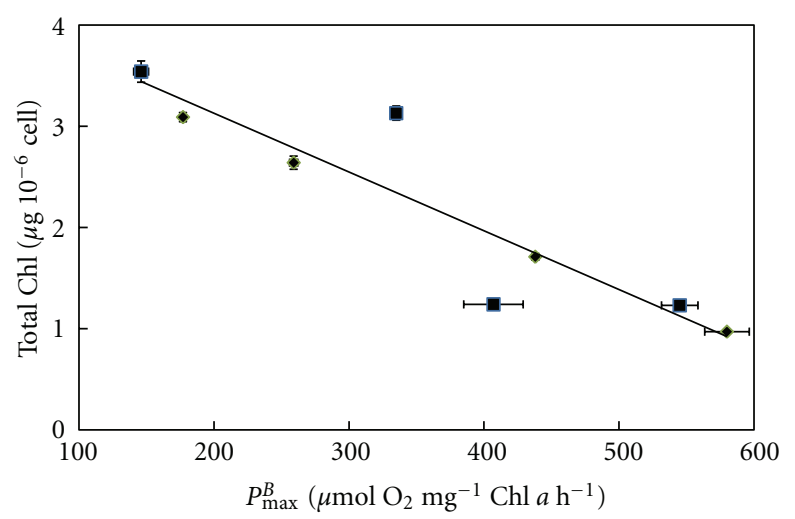

(b)

Figure 2: (a) Relationship between $\alpha^{B}$ calculated from gross photosynthesis versus light intensity curves $(P / E$ in Figure 1$)$ and Chl a/Chl $c$ ratio (Table 1) in Amphora coffeaeformis, Amphora acutiuscula, Entomoneis paludosa, and Nitzschia palea grown in ASW in the absence ( $\square$ ) or the presence $(\diamond)$ of $\mathrm{Zn}$ supplementation. (b) Relationship between the total Chl content (Table 1) and the maximum gross photosynthesis $\left(P_{\max }^{B}\right)$ (Figure 1) in Amphora coffeaeformis, Amphora acutiuscula, Entomoneis paludosa, and Nitzschia palea grown in ASW in the absence $(\mathbf{\square})$ or the presence $(\checkmark)$ of $\mathrm{Zn}$ supplementation.

behavior could be explained by the involvement of other mechanisms such as Mehler reaction, cyclic electron transport around PSII and/or PSI, photorespiration, and lightdependent mitochondrial respiration. The intensity of these mechanisms depends on the experimental conditions [50]. We observed that the $\mathrm{Zn}$ supplementation restored the proportionality between the two parameters, suggesting that $\mathrm{Zn}$ may target some component(s) of the electron transfer chain (Figure 4). The cytochrome of the electron transport chain can be proposed as a putative target of $\mathrm{Zn}$ ions in excess. Actually, it has been shown that $\mathrm{Zn}$ ions interact with the $\mathrm{Q}_{0}$ pocket of cytochrome $\mathrm{b}_{6} / \mathrm{f}$ complex [51]. These ions have also been shown to impair the proton transport function of cytochromes in bacteria and mitochondria [52]. Because the structure of cytochrome has been highly conserved during evolution $[53,54]$, this possibility is also likely.

In N. palea, Zn slowed down both oxygen evolution and the electron transport rates, with the rETR being more presence at the highest photon flux densities $(>800 \mu \mathrm{mol}$ photon PAR m ${ }^{-2} \mathrm{~s}^{-1}$ ) than the oxygen evolution rate. Several nonexclusive causes can be involved in this inhibition: (i) photoinhibition due to a reduced activity of the xanthophyll cycle: the cycle consists in the reversible conversion of diadinoxanthin to diatoxanthin. It is activated by the acidification of the thylakoid. It is used as a photoprotection mechanism allowing the dissipation of the excess of energy absorbed by PSII. When this capacity is over, the photoinhibition starts $[55,56]$. In our conditions, an impairment of the xanthophyll cycle is unlikely as no photoinhibition was observed (Figures 1 and 3). If this phenomenon would occur, both $P / E$ and $\mathrm{rETR} / E$ curves would have presented a strong decreasing phase at high photon flux densities. So far the only metal known to inhibit the xanthophyll cycle activity in diatoms is cadmium [57]. (ii) PSII inhibition: it can be due to the impairment of the water oxidizing enzymes itself or/and by the destabilization of the binding cofactors in the oxygen evolving polypeptides associated with PSII [58]. For instance, Vaillant et al. [59] established that the replacement of $\mathrm{Mn}^{2+}$ in the water oxidizing complex by $\mathrm{Zn}^{2+}$ leads to a reduction of oxygen emission. Altogether these data indicate that in $N$. palea, the reduction of photosynthetic activity triggered by the excess of $\mathrm{Zn}$ explains the lower maximum cell density presented in Table 1 , with the cell becoming at this $\mathrm{Zn}$ concentration unable to cope with its toxicity. (iii) A shortage of carbon supply: Subrahmanyam and Rathore [60] found that a reduced demand for ATP and NADPH in the Calvin cycle causes a downregulation of PSII photochemistry. On the other hand, Sunda and Huntsman [61] have identified a relationship between the addition of $\mathrm{Zn}$ and the $\mathrm{C}$ fixating rate at saturating light intensity in the diatom Thalassiosira pseudonana and in higher plants, $\mathrm{Zn}$ can inhibit the carboxylase activity of RuBisCO, leading intact the oxygenase capacity [62].

In diatoms, carbonic anhydrase, a $\mathrm{Zn}$-dependent enzyme catalyses the reversible interconversion of $\mathrm{HCO}_{3}{ }^{-}$and $\mathrm{CO}_{2}$ and is an important component of the inorganic carbon concentration mechanism [63-65]. This enzyme supplies RubisCO with $\mathrm{CO}_{2}[27,66]$. The positive effects of $\mathrm{Zn}$ on the photosynthetic activity of $A$. coffeaeformis suggest that the amount of $\mathrm{Zn}$ in the ASW constitutes a limiting factor (Figures 1 and 3) that could limit the CA activity. In order to test this hypothesis, the effect of $\mathrm{Zn}$-supplementation on the CA activity was measured. These data are presented in the next section.

3.4. Effects of Zinc on Carbonic Anhydrase Activity. In the absence of the Zn-supplementation, the carbonic anhydrase activity was detected at the cell surface (external CA) and in the cytosol (internal CA) in all four diatoms, with the highest total activity being found in A. coffeaeformis and N. palea. The addition of $\mathrm{Zn}$ did not stimulate CA activity except the 


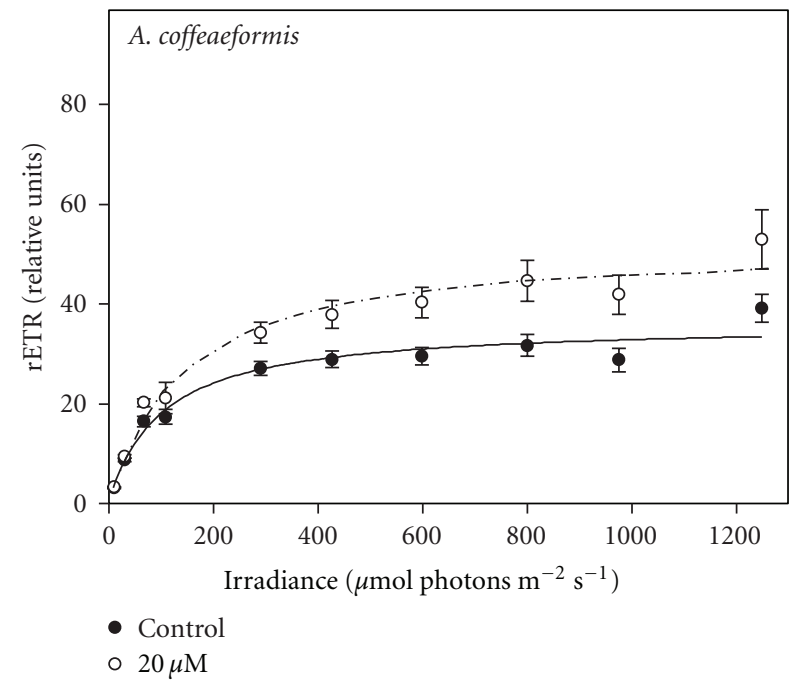

(a)

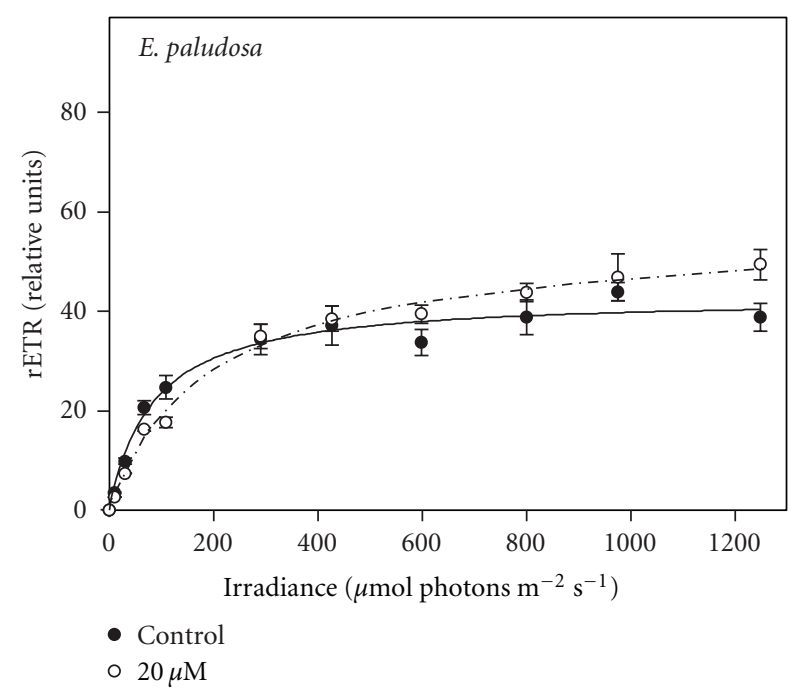

(c)

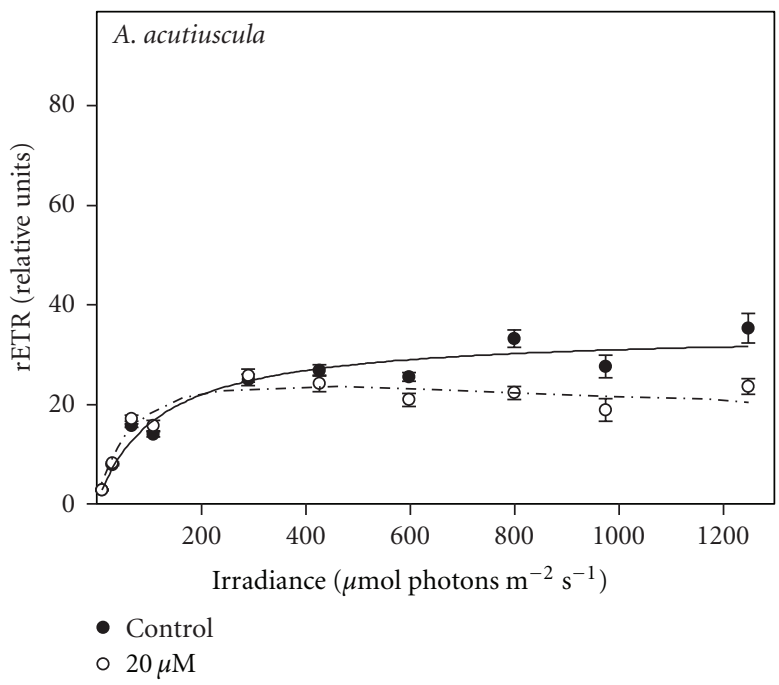

(b)

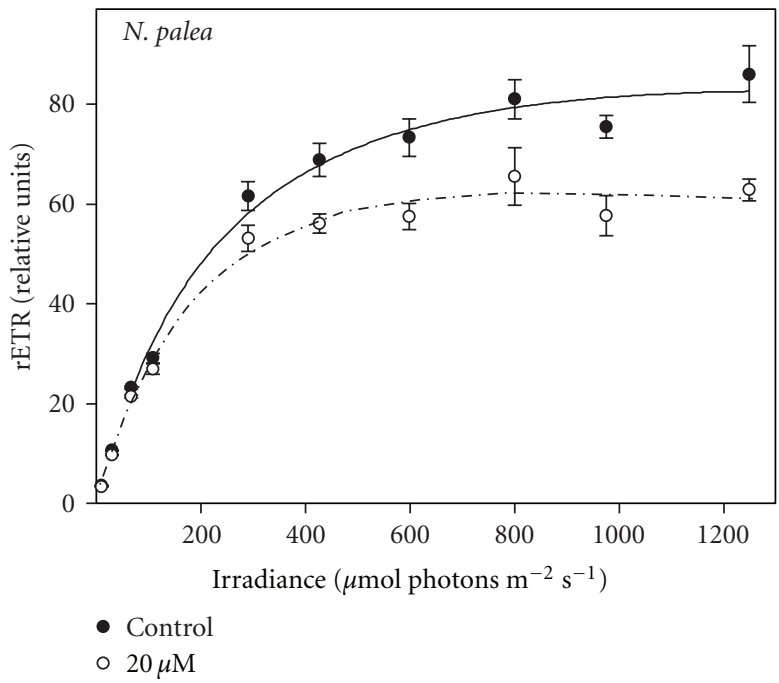

(d)

FIGURE 3: Relative electron transport rate (rETR) versus irradiance curves in Amphora coffeaeformis, Amphora acutiuscula, Entomoneis paludosa, and Nitzschia palea grown in ASW (control) or in the presence of $20 \mu \mathrm{M} \mathrm{Zn}$ added to ASW. Mean values \pm SE $(n=3-5)$.

$\mathrm{CA}_{\text {ext }}$ activity in E. paludosa (Figure 5). It can be noticed that the weak increase of $\mathrm{CA}_{\text {ext }}$ activity in A. acutiuscula could be reflected in the higher photosynthetic activity (Figures 1 and 3).

It is well established that metal stresses induce the production of ROS that disturbs the functioning of the different cell compartments [15]. To test this possibility in our growth conditions, the total activity of the main antioxidant enzymes that is, SOD, APX, and CAT were measured after 5 days of growth in the presence or the absence of $\mathrm{Zn}$-supplementation.

3.5. Antioxidant Enzymatic Activities. Each taxon presented an activity APX, CAT, and SOD in the absence of Zn-supplementation but with different relative intensities (Figure 6). In the four species, the SOD activity represented about $70 \%$ the total antioxidant activity measured, the remaining activities being shared unequally between APX and CAT activities. For instance, in E. paludosa, the CAT activity was 12 times higher than the APX one (Figure 6).

In the $\mathrm{Zn}$-supplemented growth medium, the activity of the three antioxidant enzymes did not display any clear increase, except the APX activity in N. palea that increased by $22 \%$. However, we could not exclude the possibility that the activity of the enzymes is modified in individual cell compartments, such as the chloroplasts, in which the ROS production can elevate in case of photosynthetic impairment (reviewed in [5]), these results presented here suggest that in our conditions, the excess of $\mathrm{Zn}$ did not triggered an intensive oxidative stress requiring additional antioxidative enzymes to cope with Pinto et al. [67] have shown that in Pavlova viridis an excess of $\mathrm{Zn}($ c.a. $50 \mu \mathrm{M})$ enhanced lipid 

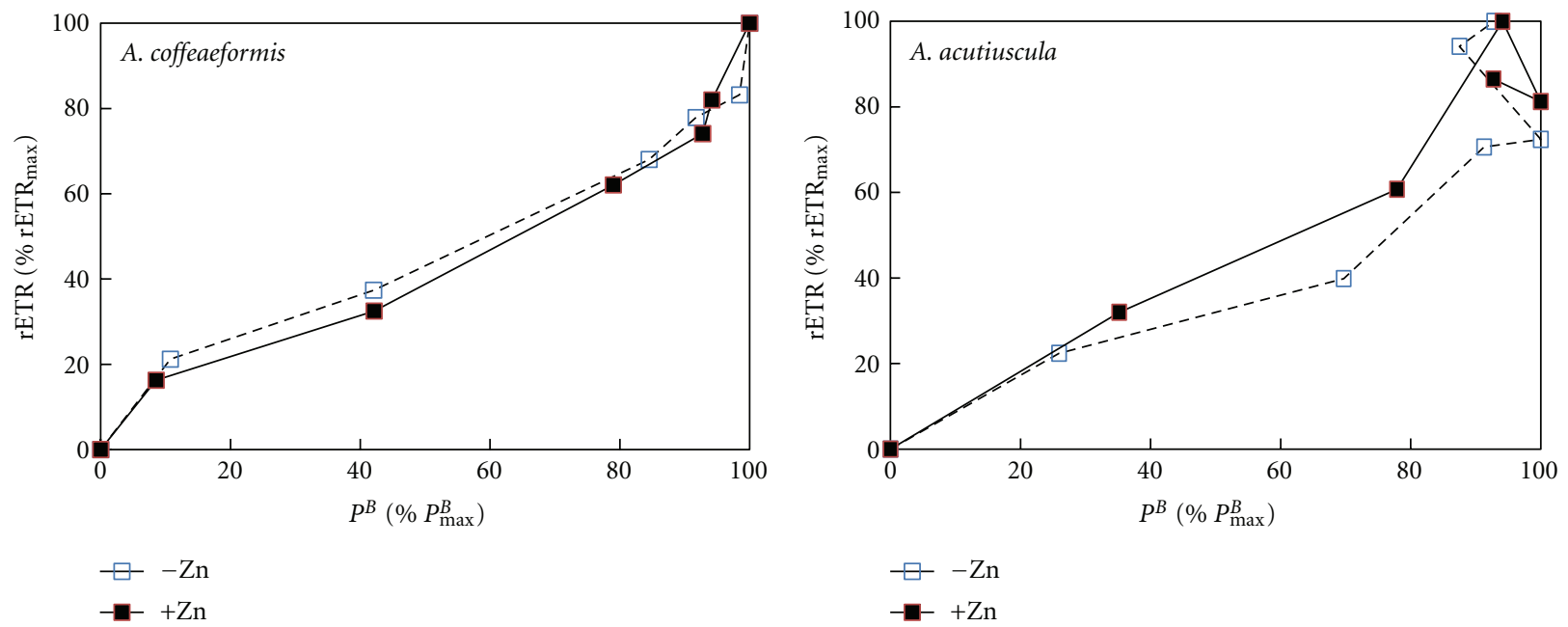

(a)

(b)
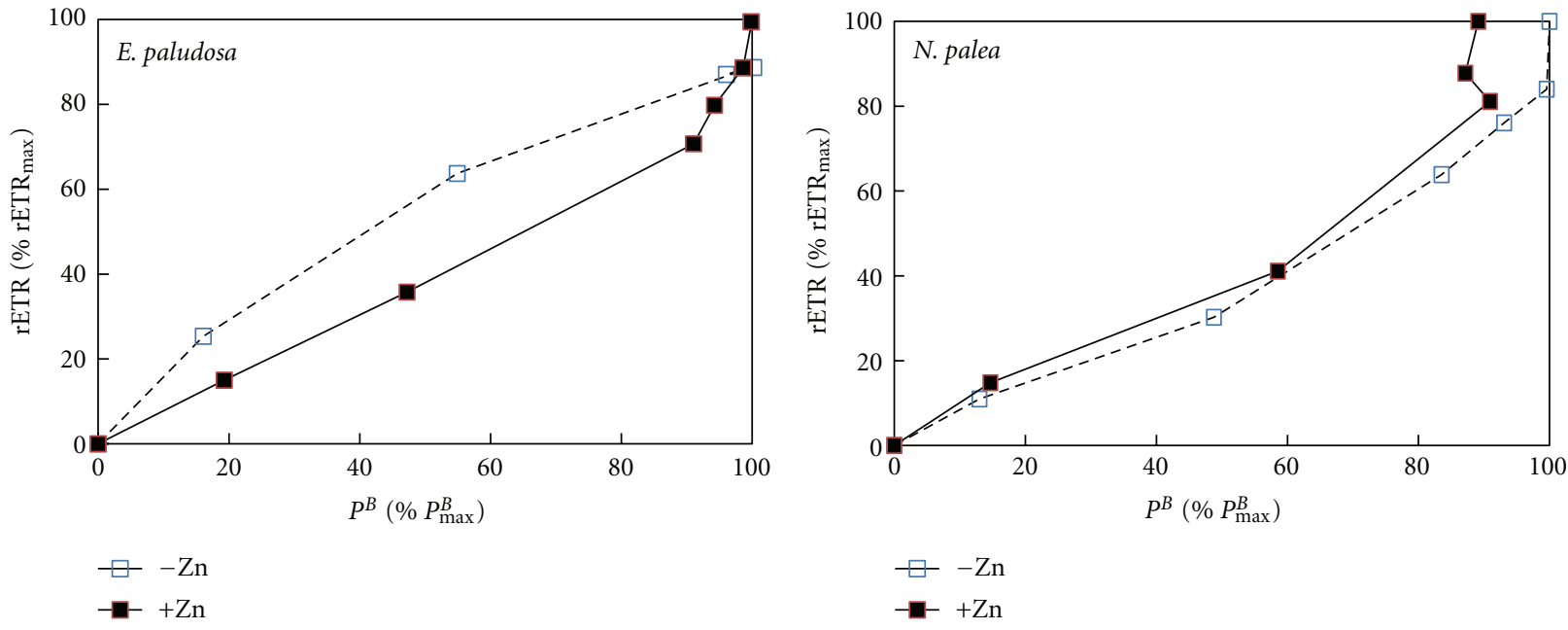

(c)

(d)

FIGURE 4: Relationship between the relative intensity of rETR and the relative intensity of $P^{B}$ in Amphora coffeaeformis, Amphora acutiuscula, Entomoneis paludosa, and Nitzschia palea grown in the absence $(\square)$ or the presence $(\square)$ of a Zn supplementation.

peroxidation, which can be considered as an indication of the oxidation damages. Alternatively, we can suggest that a part of the ions in excess is quenched, with the remaining part being unable to trigger an intense oxidative stress. So far, two main mechanisms of ion quenching have been found to be active in algae, including diatoms (reviewed in $[5,15]$ ). The first mechanism occurs outside the cells and involved the binding of the metal ions to exopolysaccharides ( $\mathrm{Zn}$ S. costatum: [16]; Cu-Amphora sp.: [10]). Although these exopolysaccharides were not quantified in this study, we observed that the four diatoms tended to agglutinate when placed in the $\mathrm{Zn}$-supplemented medium (data not shown), suggesting the production of these compounds as reported in A. coffeaeformis [68]. However, the binding capacity of the exopolysaccharides seems not intense enough to avoid $\mathrm{Zn}$ penetrating into the cells. The second mechanism occurs mostly in the cytoplasm and consists in the phytochelatins (Cu, Zn-Scenedesmus sp.: [31]; Zn-Nitzschia closterium: [6]) (reviewed in [67]). In order to test the second possibility, the genes corresponding to phytochelatin synthase were searched and their expression was measured in the different taxons grown in the presence or in the absence of $\mathrm{Zn}$ supplementation.

3.6. Partial Phytochelatin Synthase Sequences. The use of the designed primers allowed the recovery of the partial DNA sequences in each taxon studied. The DNA sequence analysis showed open reading frames ranging from 279 to $321 \mathrm{bp}$ (data not shown) coding for 92 to 106 amino acids residues, respectively, for the four taxons investigated in this study (Figure 7). Blast searches using the nucleotide sequences against those of higher plants as well as the sequenced genomes of the diatoms $P$. tricornutum and T. pseudonana revealed identities up to $100 \%$ with phytochelatin synthase gene (98\%: E. paludosa and both A. coffeaeformis; 100\%: 


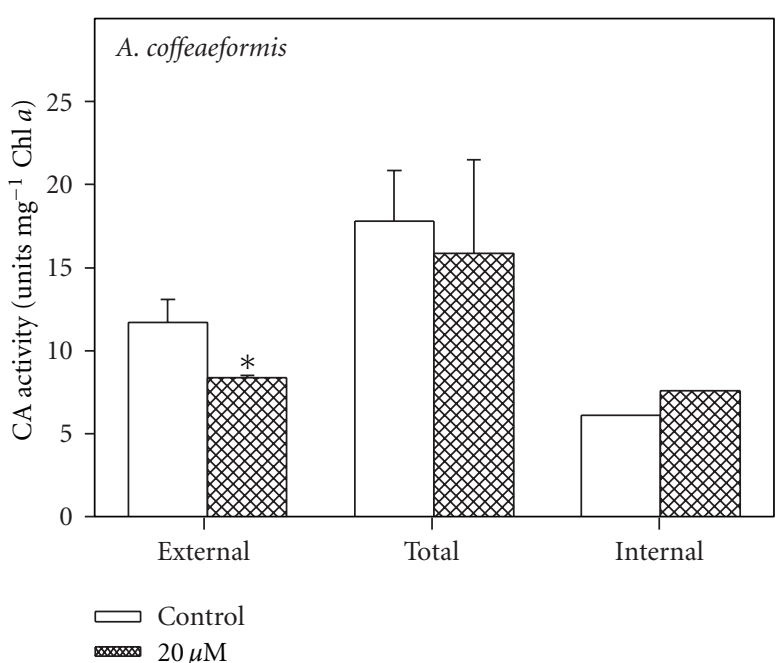

(a)

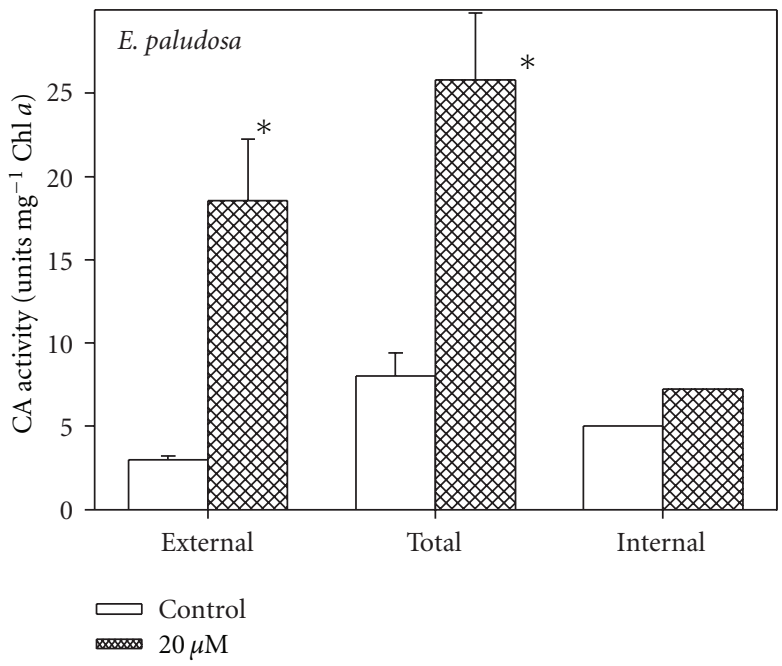

(c)

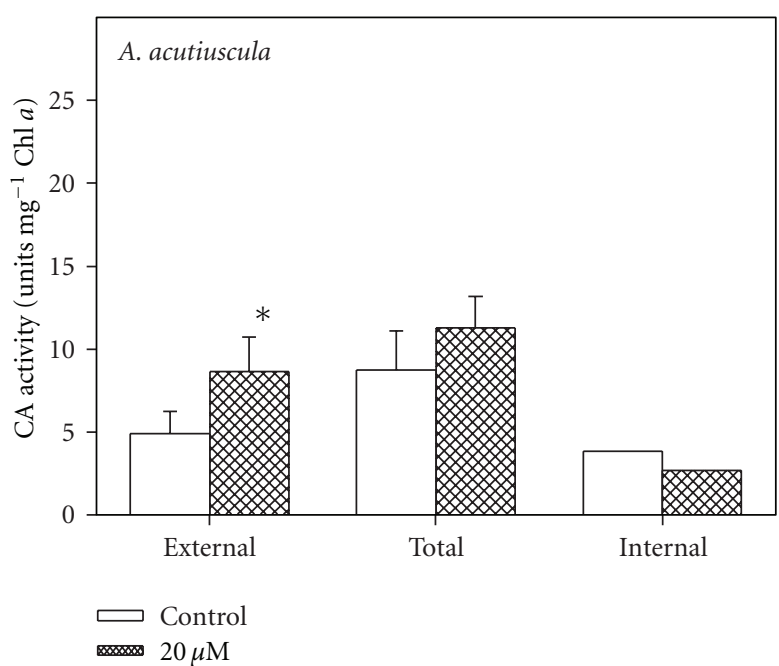

(b)

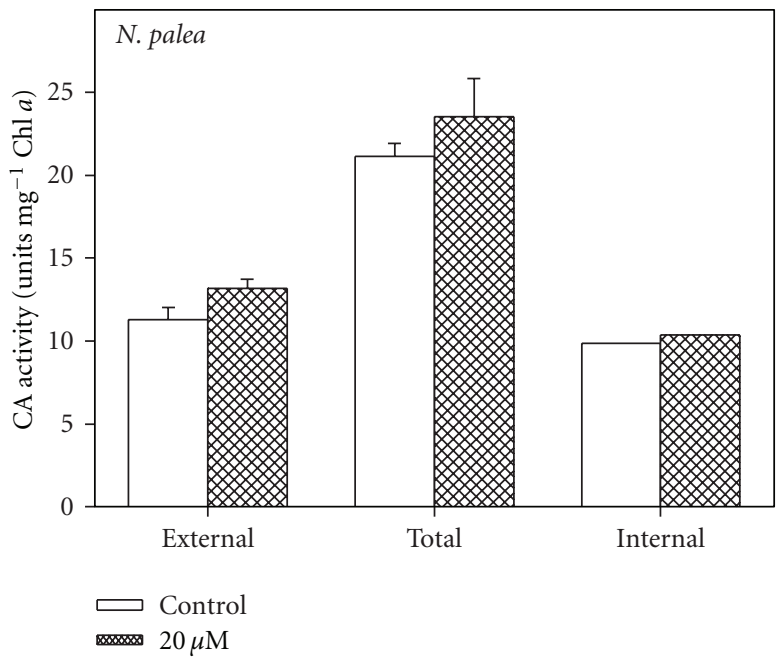

(d)

FIgURE 5: External, internal, and total carbonic anhydrase (CA) activities in Amphora coffeaeformis, Amphora acutiuscula, Entomoneis paludosa, and Nitzschia palea grown in ASW (control) or in the presence of $20 \mu \mathrm{M}$ Zn added to ASW. Mean values \pm SE $(n=3-5)$. Significant differences are indicated by an asterisk $(P \leq 0.05)$.

A. acutiuscula). The in silico translation of the openreading frames revealed the presence of four conserved cysteine residues belonging to the catalytic domain located at the $\mathrm{N}$-terminal region of the enzyme $[69,70]$ (Figure 7). Both these DNA sequences and the corresponding deduced amino acid sequences have been deposited to the EMLEBI database ( $N$. palea no. FN995985; A. coffeaeformis, no. FN995986; E. paludosa, no. FN995987; A. acutiuscula, no. FN995989). To evaluate the expression level of the phytochelatin synthase gene in the absence and in the presence of $\mathrm{Zn}$-supplementation, total RNA were extracted after 5 days of growth in the absence or the presence of $\mathrm{Zn}$ supplementation and quantified by northern blotting. The good quality of the total RNA extracted was revealed by two clearly defined electrophoretic bands corresponding to $18 \mathrm{~S}$ and $28 \mathrm{~S}$ ribosomal RNA (data not shown). Despite the fact that $\mathrm{Zn}$ is the second best inducer of phytochelatin synthesis [71], the mRNAs corresponding to phytochelatin synthase were only detected in equal amount in $N$. palea in the presence or in the absence of $\mathrm{Zn}$-supplementation (data not shown), and using this method, no change in the expression level was suspected due to the presence of the $Z n$ supplementation. Interestingly, the diatom $P$. tricornutum did not express phytochelatin synthase for a $\mathrm{Zn}$ concentration one order lower than our $(2.2 \mu \mathrm{M}$ : [72]). On the other hand, $\mathrm{Zn}$ has been reported to trigger phytochelatin synthesis in the green alga Dunaliella tertiolecta for a $\mathrm{Zn}$ concentration one order higher than the one used in this study $(200 \mu \mathrm{M}$ : [73]). This suggests that each taxon would sense the $\mathrm{Zn}$ internal concentration and would express the phytochelatin synthase gene according to a threshold, with this level being one ecological characteristic of this taxon. Our data suggest that this minimum level was crossed only in the case of $N$. palea. The synthesis of phytochelatins would then contribute 


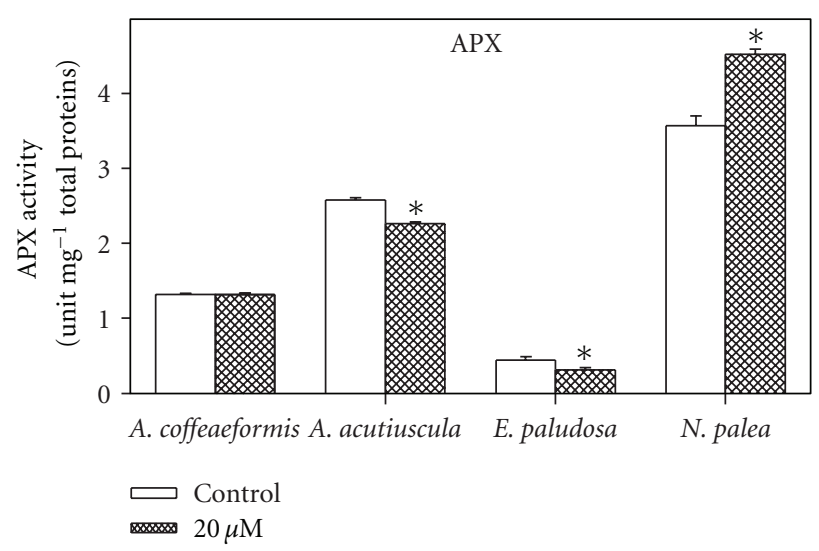

(a)

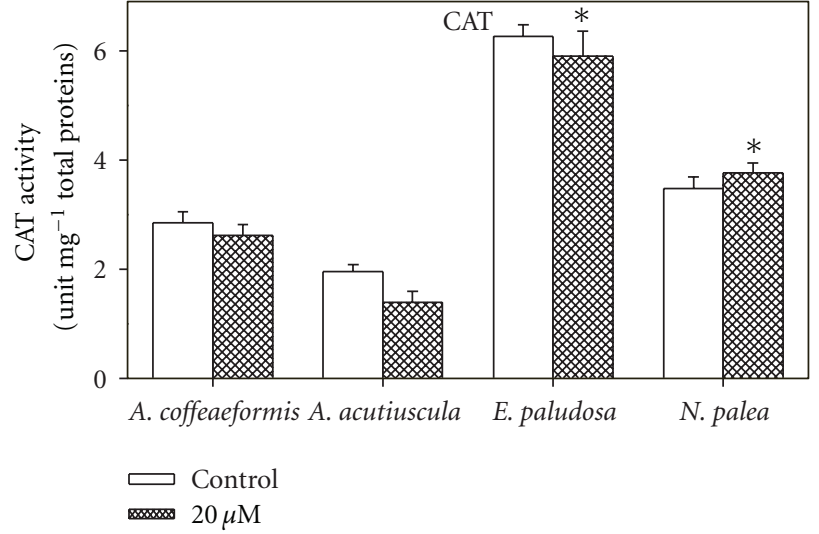

(b)

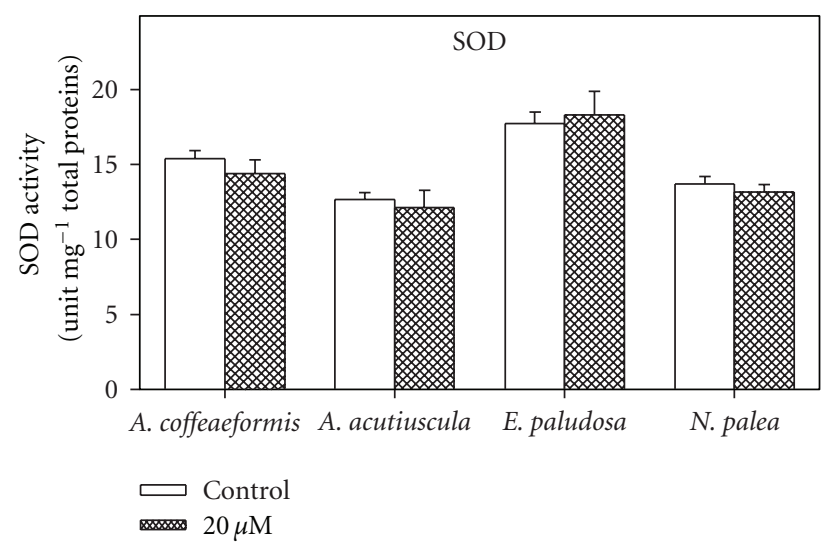

(c)

FIgURE 6: Antioxidant enzymes activities (superoxide dismutase, SOD; catalase, CAT and ascorbate peroxidase, APX) in Amphora coffeaeformis, Amphora acutiuscula, Entomoneis paludosa, and Nitzschia palea grown in ASW (control) or in the presence of $20 \mu \mathrm{M} Z \mathrm{n}$ added to ASW. Significant differences are indicated by an asterisk $(P \leq 0.05)$. Mean values \pm SE $(n=3-5)$.

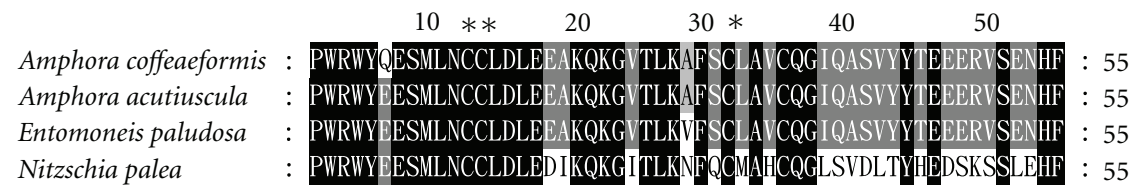

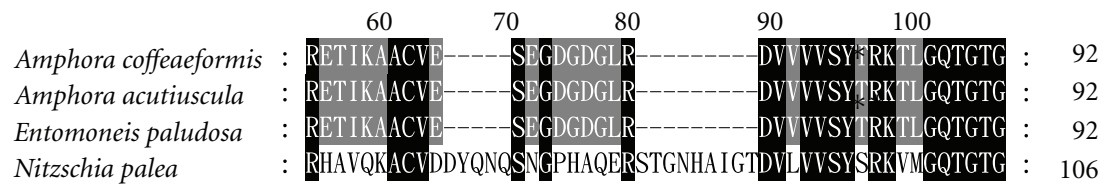

Figure 7: Alignment of the amino acid sequences of phytochelatin synthase fragments isolated from Amphora acutiuscula (FN995989), Amphora coffeaeformis (FN995985), Entomoneis paludosa (FN995987) and Nitzschia palea (FN995985) grown in ASW. Black boxes indicated $100 \%$ identity, dark grey $80 \%$, and light grey $60 \%$. The cysteine residues are indicated by asterisks.

to the resistance of N. palea in Zn-supplemented growth medium. This result also confirms that this taxon is especially sensitive to $\mathrm{Zn}$ elevation. More investigations are needed to find out whether the phytochelatin synthase genes are completely repressed or slightly expressed in the other three species.

\section{Conclusions}

A $\mathrm{Zn}$ supplementation to the growth medium has different effects on the metabolism of diatoms. Of the four diatoms tested, E. paludosa was found to be the most sensitive taxon to $\mathrm{Zn}$ supplementation since its growth is drastically decreased. 
This study also showed that Zn in ASW is a limiting factor for both Amphora species. A. coffeaeformis is the most tolerant species in our culture condition. In N. palea, a higher antioxidant enzyme activity and the expression of phytochelatin gene are mechanisms providing cellular tools to cope with the excess of $\mathrm{Zn}$ and allowing the cells to develop equally to the tolerant species $A$. coffeaeformis.

\section{Acknowledgments}

The authors thank Dr. Y. Rincé for identifying the diatoms. The Embassy of French Republic at Hanoï is thanked for the fellowship to T. L. N. Nguyen-Deroche. The authors are grateful to P. Gaudin (Nantes Culture Collection) for the supply of the diatoms.

\section{References}

[1] E. Granum, J. A. Raven, and R. C. Leegood, "How do marine diatoms fix 10 billion tonnes of inorganic carbon per year?" Canadian Journal of Botany, vol. 83, no. 7, pp. 898-908, 2005.

[2] C. A. Atkins, B. D. Patterson, and D. Graham, "Plant carbonic anhydrases. II preparation and some properties of monocotyledon and dicotyledon enzyme types," Plant Physiology, vol. 50, no. 2, pp. 218-223, 1972.

[3] J. L. Riechmann and O. J. Ratcliffe, "A genomic perspective on plant transcription factors," Current Opinion in Plant Biology, vol. 3, no. 5, pp. 423-434, 2000.

[4] I. Flor-Parra, M. Vranes, J. Kämper, and J. Pérez-Martín, "Biz1, a zinc finger protein required for plant invasion by Ustilago maydis, regulates the levels of a mitotic cyclin," Plant Cell, vol. 18, no. 9, pp. 2369-2387, 2006.

[5] M. Bertrand and I. Poirier, "Photosynthetic organisms and excess of metals," Photosynthetica, vol. 43, no. 3, pp. 345-353, 2005.

[6] J. L. Stauber and T. M. Florence, "Mechanism of toxicity of zinc to the marine diatom Nitzschia closterium," Marine Bio$\log y$, vol. 105, no. 3, pp. 519-524, 1990.

[7] A. Cid, C. Herrero, E. Torres, and J. Abalde, "Copper toxicity on the marine microalga Phaeodactylum tricornutum: effects on photosynthesis and related parameters," Aquatic Toxicology, vol. 31, no. 2, pp. 165-174, 1995.

[8] S. Gagneux-Moreaux, Les métaux ( $\mathrm{Cd}, \mathrm{Cu}, \mathrm{Pb}$ et $\mathrm{Zn})$ dans la production des microalgues sur différents milieux de culture: biodisponibilité, bioaccumulation et impact physiologique, Ph.D. thesis, Nantes university, 2006.

[9] W. M. El-Sarraf and O. E. Taha, "Effets of copper on photosynthetic activity and chlorophyll-a content of Chaetoceros radicans Schütt," Bulletin of the High Institute of Public Health, vol. 25, no. 2, pp. 439-446, 1995.

[10] T. L. N. Nguyen-Deroche, T. T. Le, T. V. Bui, Y. Rincé, G. Tremblin, and A. Morant-Manceau, "Effects of copper on growth and photosynthesis in marine diatoms: a comparison between species from two different geographical areas," Cryptogamie, Algologie, vol. 30, no. 2, pp. 97-109, 2009.

[11] M. Li, C. Hu, Q. Zhu, L. Chen, Z. Kong, and Z. Liu, "Copper and zinc induction of lipid peroxidation and effects on antioxidant enzyme activities in the microalga Pavlova viridis (Prymnesiophyceae)," Chemosphere, vol. 62, no. 4, pp. 565572, 2006.

[12] J. W. Rijstenbil, J. W. M. Derksen, L. J. A. Gerringa et al., "Oxidative stress induced by copper: defense and damage in the marine planktonic diatom Ditylum brightwellii, grown in continuous cultures with high and low zinc levels," Marine Biology, vol. 119, no. 4, pp. 583-590, 1994.

[13] J. W. Rijstenbil, "Effects of UVB radiation and salt stress on growth, pigments and antioxidative defence of the marine diatom Cylindrotheca closterium," Marine Ecology Progress Series, vol. 254, pp. 37-48, 2003.

[14] D. Branco, A. Lima, S. F. P. Almeida, and E. Figueira, "Sensitivity of biochemical markers to evaluate cadmium stress in the freshwater diatom Nitzschia palea (Kützing) W. Smith," Aquatic Toxicology, vol. 99, no. 2, pp. 109-117, 2010.

[15] K. Solymosi and M. Bertrand, "Soil metals, chloroplasts, and secure crop production: a review," Agronomy for Sustainable Environment, vol. 32, no. 1, pp. 245-272, 2010.

[16] B. E. Imber, M. G. Robinson, A. M. Ortega, and J. D. Burton, "Complexation of zinc by exudates from Skeletonema costatum grown in culture," Marine Chemistry, vol. 16, no. 2, pp. 131139,1985

[17] E. Grill, S. Loffler, E. L. Winnacker, and M. H. Zenk, "Phytochelatins, the heavy-metal-binding peptides of plants, are synthesized from glutathione by a specific $\gamma$-glutamylcysteine dipeptidyl transpeptidase (phytochelatin synthase)," Proceedings of the National Academy of Sciences of the United States of America, vol. 86, no. 18, pp. 6838-6842, 1989.

[18] F. Sylvestre, B. Beck-Eichler, W. Duleba, and J. P. Debenay, "Modern benthic diatom distribution in a hypersaline coastal lagoon: the lagoa de araruama (R.J.), Brazil," Hydrobiologia, vol. 443, pp. 213-231, 2001.

[19] M. Rech, J.-L. Mouget, A. Morant-Manceau, P. Rosa, and G. Tremblin, "Long-term acclimation to UV radiation: effects on growth, photosynthesis and carbonic anhydrase activity in marine diatoms," Botanica Marina, vol. 48, no. 5-6, pp. 407420, 2005.

[20] M. Fouqueray, J. L. Mouget, A. Morant-Manceau, and G. Tremblin, "Dynamics of short-term acclimation to UV radiation in marine diatoms," Journal of Photochemistry and Photobiology B, vol. 89, no. 1, pp. 1-8, 2007.

[21] P. J. Harrison, R. E. Waters, and F. J. R. Taylor, "A broad spectrum artificial seawater medium for coastal and open ocean phytoplankton," Journal of Phycology, vol. 16, no. 1, pp. 28-35, 1980.

[22] B. J. Speziale, S. P. Schreiner, P. A. Giammatteo, and J. E. Schindler, "Comparison of N,N- dimethylformamide, dimethyl sulfoxide, and acetone for extraction of phytoplankton chlorophyll," Canadian Journal of Fisheries and Aquatic Sciences, vol. 41, no. 10, pp. 1519-1522, 1984.

[23] P. H. C. Eilers and J. C. H. Peeters, "A model for the relationship between light intensity and the rate of photosynthesis in phytoplankton," Ecological Modelling, vol. 42, no. 3-4, pp. 199215, 1988.

[24] M. Rech, J.-L. Mouget, and G. Tremblin, "Modification of the Hansatech FMS fluorometer to facilitate measurements with microalgal cultures," Aquatic Botany, vol. 77, no. 1, pp. 71-80, 2003.

[25] J.-L. Mouget, G. Tremblin, A. Morant-Manceau, M. Morançais, and J. M. Robert, "Long-term photoacclimation of Haslea ostrearia (Bacillariophyta): effect of irradiance on growth rates, pigment content and photosynthesis," European Journal of Phycology, vol. 34, no. 2, pp. 109-115, 1999.

[26] M. Dionisio-Sese and S. Miyachi, "The effect of sodium chloride on carbonic anhydrase activity in marine microalgae," Journal of Phycology, vol. 28, no. 5, pp. 619-624, 1992.

[27] A. Morant-Manceau, T. L. N. Nguyen, E. Pradier, and G. Tremblin, "Carbonic anhydrase activity and photosynthesis in 
marine diatoms," European Journal of Phycology, vol. 42, no. 3, pp. 263-270, 2007.

[28] H. Aebi, "Catalase in vitro," Methods in Enzymology, vol. 105, pp. 121-126, 1984.

[29] Y. Nakano and K. Asada, "Hydrogen peroxide is scavenged by ascorbate-specific peroxidase in spinach chloroplasts," Plant and Cell Physiology, vol. 22, no. 5, pp. 867-880, 1981.

[30] E. Morelli and G. Scarano, "Copper-induced changes of nonprotein thiols and antioxidant enzymes in the marine microalga Phaeodactylum tricornutum," Plant Science, vol. 167, no. 2, pp. 289-296, 2004.

[31] B. N. Tripathi, S. K. Mehta, A. Amar, and J. P. Gaur, "Oxidative stress in Scenedesmus sp. during short- and long-term exposure to $\mathrm{Cu}^{2+}$ and $\mathrm{Zn}^{2+}$," Chemosphere, vol. 62, no. 4, pp. 538-544, 2006.

[32] E. F. Hartree, "Determination of protein: a modification of the lowry method that gives a linear photometric response," Analytical Biochemistry, vol. 48, no. 2, pp. 422-427, 1972.

[33] J. J. Doyle and J. L. Doyle, "Isolation of plant DNA from fresh tissue," Focus, vol. 12, pp. 13-15, 1990.

[34] S. F. Altschul, W. Gish, W. Miller, E. W. Myers, and D. J. Lipman, "Basic local alignment search tool," Journal of Molecular Biology, vol. 215, no. 3, pp. 403-410, 1990.

[35] K. B. Nicholas and H. B. Nicholas, "GENEDOC a Tool for Editing and Annoting Multiple Sequence," Alignments, 1997, http://www.psc.edu/biomed/genedoc.

[36] J. Sambrook, E. F. Fritsch, and T. Maniatis, Molecular Cloning: A laboratory Manual, Cold Spring Harbor Laboratory Press, Cold Spring Harbor, NY, USA, 1989.

[37] H. Hu, Y. Shi, W. Cong, and Z. Cai, "Growth and photosynthesis limitation of marine red tide alga Skeletonema costatum by low concentrations of $\mathrm{Zn}^{2+}$," Biotechnology Letters, vol. 25, no. 22, pp. 1881-1885, 2003.

[38] E. Morelli and G. Scarano, "Synthesis and stability of phytochelatins induced by cadmium and lead in the marine diatom Phaeodactylum tricornutum," Marine Environmental Research, vol. 52, no. 4, pp. 383-395, 2001.

[39] M. Lamote, E. Darko, B. Schoefs, and Y. Lemoine, "Assembly of the photosynthetic apparatus in embryos from Fucus serratus L.," Photosynthesis Research, vol. 77, no. 1, pp. 45-52, 2003.

[40] K. Kralova, E. Masarovicova, and K. Gyoryova, "The physiological response of green algae (Chlorella vulgaris) to $\mathrm{pH}$ dependent inhibitory activity of some zinc(II) compounds: carboxylato- and halogenocarboxylatozinc(II) complexes," Chemical Papers, vol. 58, no. 5, pp. 353-356, 2004.

[41] S. A. Shehata, M. R. Lasheen, G. H. Ali, and I. A. Kobbia, "Toxic effect of certain metals mixture on some physiological and morphological characteristics of freshwater algae," Water, Air, and Soil Pollution, vol. 110, no. 1-2, pp. 119-135, 1999.

[42] N. S. Fisher, G. J. Jones, and D. M. Nelson, "Effects of copper and zinc on growth, morphology, and metabolism of Asterionella japonica (Cleve)," Journal of Experimental Marine Biology and Ecology, vol. 51, no. 1, pp. 37-56, 1981.

[43] H. H. Omar, "Bioremoval of zinc ions by Scenedesmus obliquus and Scenedesmus quadricauda and its effect on growth and metabolism," International Biodeterioration and Biodegradation, vol. 50, no. 2, pp. 95-100, 2002.

[44] L. Rai, A. Sing, and N. Mallick, "Studies on photosynthesis, the associated electron transport system and some physiological variables of Chlorella vulgaris under heavy metal stress," Journal of Plant Physiology, vol. 137, no. 4, pp. 419-424, 1991.

[45] S. I. Beale, "Enzymes of chlorophyll biosynthesis," Photosynthesis Research, vol. 60, no. 1, pp. 43-73, 1999.
[46] R. A. Danilov and N. G. A. Ekelund, "Effects of $\mathrm{Cu}^{2+}, \mathrm{Ni}^{2+}$, $\mathrm{Pb}^{2+}, \mathrm{Zn}^{2+}$ and pentachlorophenol on photosynthesis and motility in Chlamydomonas reinhardtii in short-term exposure experiments," The BMC Ecology, vol. 1, article 1, 2001.

[47] B. Koukal, C. Guéguen, M. Pardos, and J. Dominik, "Influence of humic substances on the toxic effects of cadmium and zinc to the green alga Pseudokirchneriella subcapitata," Chemosphere, vol. 53, no. 8, pp. 953-961, 2003.

[48] S. Lefebvre, J.-L. Mouget, P. Loret, P. Rosa, and G. Tremblin, "Comparison between fluorimetry and oximetry techniques to measure photosynthesis in the diatom Skeletonema costatum cultivated under simulated seasonal conditions," Journal of Photochemistry and Photobiology B, vol. 86, no. 2, pp. 131139, 2007.

[49] M. Kühl, R. N. Glud, J. Borum, R. Roberts, and S. Rysgaard, "Photosynthetic performance of surface-associated algae below sea ice as measured with a pulse-amplitude-modulated (PAM) fluorometer and $\mathrm{O}_{2}$ microsensors," Marine Ecology Progress Series, vol. 223, pp. 1-14, 2001.

[50] I. A. Flameling and J. Krompkamp, "Light dependence of quantum yields for PSII charge separation and oxygen evolution in eukaryotic algae," Limnology and oceanography, vol. 43, no. 2, pp. 284-287, 1998.

[51] A. G. Roberts, M. K. Bowman, and D. M. Kramer, "Certain metal ions are inhibitors of cytochrome $b_{6} f$ complex "Rieske" iron-sulfur protein domain movements," Biochemistry, vol. 41, no. 12, pp. 4070-4079, 2002.

[52] L. Giachini, F. Francia, G. Veronesi et al., "X-ray absorption studies of $\mathrm{Zn}^{2+}$ binding sites in bacterial, avian, and bovine cytochrome bc1 complexes," Biophysical Journal, vol. 93, no. 8, pp. 2934-2951, 2007.

[53] M. Kügler, V. Kruft, U. K. Schmitz, and H.-P. Braun, "Characterization of the PetM subunit of the $b_{6} f$ complex from higher plants," Journal of Plant Physiology, vol. 153, no. 5-6, pp. 581-586, 1998.

[54] J. F. Allen, "Cytochrome $b_{6} f$ : structure for signalling and vectorial metabolism," Trends in Plant Science, vol. 9, no. 3, pp. 130-137, 2004.

[55] M. Bertrand, "Carotenoid biosynthesis in diatoms," Photosynthesis Research, vol. 106, no. 1-2, pp. 89-102, 2010.

[56] Y. Lemoine and B. Schoefs, "Secondary ketocarotenoid astaxanthin biosynthesis in algae: a multifunctional response to stress," Photosynthesis Research, vol. 106, no. 1-2, pp. 155-177, 2010.

[57] M. Bertrand, B. Schoefs, P. Siffel, K. Rohacek, and I. Molnar, "Cadmium inhibits epoxidation of diatoxanthin to diadinoxanthin in the xanthophyll cycle of the marine diatom Phaeodactylum tricornutum," The FEBS Letters, vol. 508, no. 1, pp. 153-156, 2001.

[58] A. Rashid, E. L. Camm, and A. K. M. Ekramoddoullah, "Molecular mechanism of action of $\mathrm{Pb}^{2+}$ and $\mathrm{Zn}^{2+}$ on water oxidizing complex of photosystem II," The FEBS Letters, vol. 350, no. 2-3, pp. 296-298, 1994.

[59] N. Vaillant, F. Monnet, A. Hitmi, H. Sallanon, and A. Coudret, "Comparative study of responses in four Datura species to a zinc stress," Chemosphere, vol. 59, no. 7, pp. 1005-1013, 2005.

[60] D. Subrahmanyam and V. S. Rathore, "Influence of manganese toxicity on photosynthesis in ricebean (Vigna umbellata) seedlings," Photosynthetica, vol. 38, no. 3, pp. 449-453, 2000.

[61] W. G. Sunda and S. A. Huntsman, "Effect of $\mathrm{CO}_{2}$ supply and demand on zinc uptake and growth limitation in a coastal diatom," Limnology and Oceanography, vol. 50, no. 4, pp. 1181-1192, 2005. 
[62] F. Monnet, N. Vaillant, P. Vernay, A. Coudret, H. Sallanon, and A. Hitmi, "Relationship between PSII activity, $\mathrm{CO}_{2}$ fixation, and $\mathrm{Zn}, \mathrm{Mn}$ and $\mathrm{Mg}$ contents of Lolium perenne under zinc stress," Journal of Plant Physiology, vol. 158, no. 9, pp. 11371144, 2001.

[63] K. Aizawa and S. Miyachi, "Carbonic anhydrase and $\mathrm{CO}_{2}$ concentrating mechanisms in microalgae and cyanobacteria," FEMS Microbiology Letters, vol. 39, no. 3, pp. 215-233, 1986.

[64] D. Sültemeyer, C. Schmidt, and H. P. Fock, "Carbonic anhydrases in higher plants and aquatic microorganisms," Physiologia Plantarum, vol. 88, no. 1, pp. 179-190, 1993.

[65] J. V. Moroney, S. G. Bartlett, and G. Samuelsson, "Carbonic anhydrases in plants and algae," Plant, Cell and Environment, vol. 24, no. 2, pp. 141-153, 2001.

[66] T. W. Lane and F. M. M. Morel, "Regulation of carbonic anhydrase expression by zinc, cobalt, and carbon dioxide in the marine diatom Thalassiosira weissflogii," Plant Physiology, vol. 123, no. 1, pp. 345-352, 2000.

[67] E. Pinto, T. C. S. Sigaud-Kutner, M. A. S. Leitao, O. K. Okamoto, D. Morse, and P. Colepicolo, "Heavy metal-induced oxidative stress in algae," Journal of Phycology, vol. 39, no. 6, pp. 1008-1018, 2003.

[68] M. S. French and L. V. Evans, "The effects of copper and zinc on growth of the fouling diatoms Amphora and Amphiprora," Biofouling, vol. 1, pp. 3-18, 1988.

[69] C. Cobbett and P. Goldsbrough, "Phytochelatins and metallothioneins: roles in heavy metal detoxification and homeostasis," Annual Review of Plant Biology, vol. 53, pp. 159-182, 2002.

[70] N. Tsuji, N. Hirayanagi, O. Iwabe et al., "Regulation of phytochelatin synthesis by zinc and cadmium in marine green alga, Dunaliella tertiolecta," Phytochemistry, vol. 62, no. 3, pp. 453-459, 2003.

[71] J. F. Souza and W. E. Rauser, "Maize and radish sequester excess cadmium and zinc in different ways," Plant Science, vol. 165, no. 5, pp. 1009-1022, 2003.

[72] S. K. Kawakami, M. Gledhill, and E. P. Achterberg, "Production of phytochelatins and glutathione by marine phytoplankton in response to metal stress," Journal of Phycology, vol. 42, no. 5, pp. 975-989, 2006.

[73] K. Hirata, Y. Tsujimoto, T. Namba et al., "Strong induction of phytochelatin synthesis by zinc in marine green alga, Dunaliella tertiolecta," Journal of Bioscience and Bioengineering, vol. 92, no. 1, pp. 24-29, 2001. 

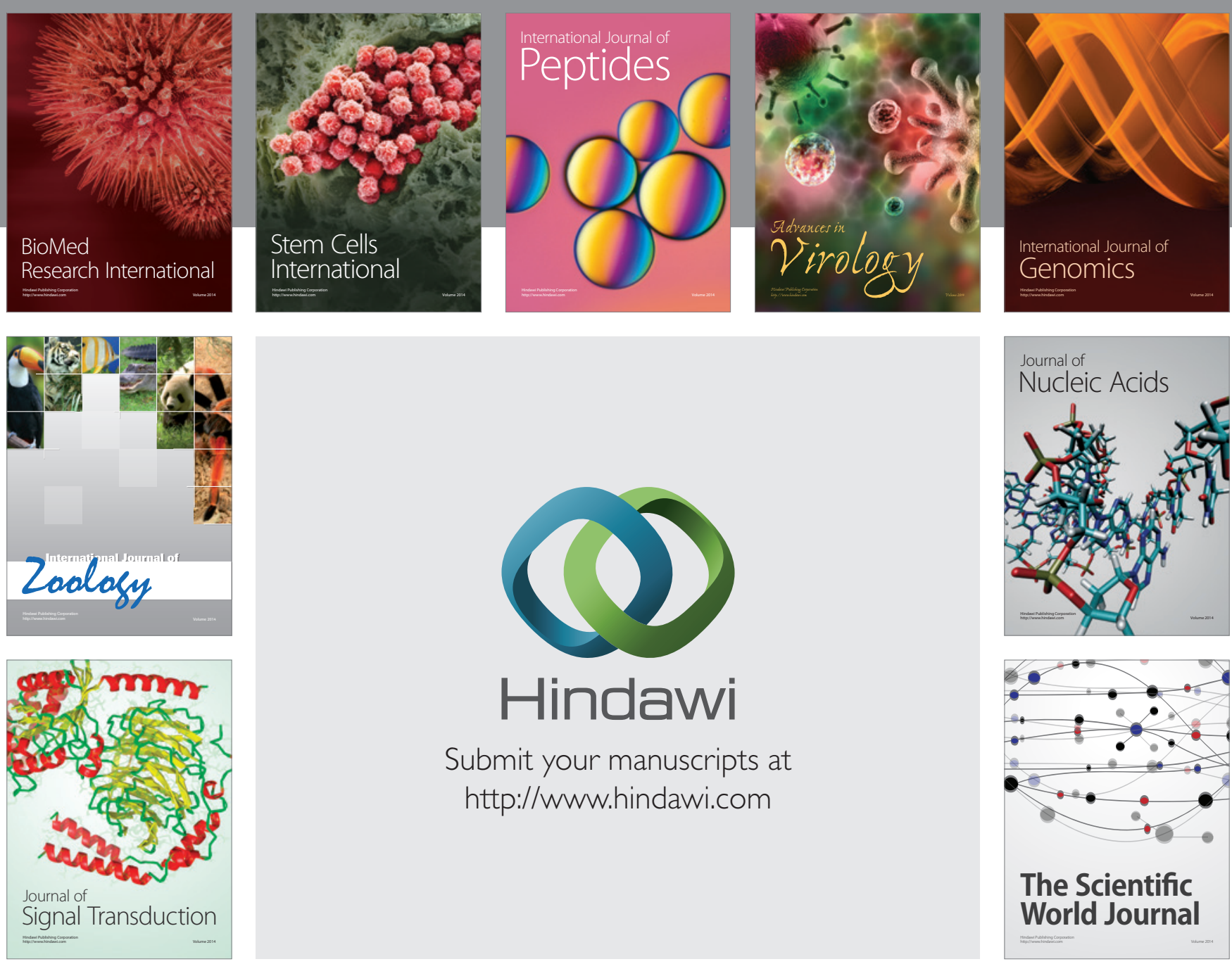

Submit your manuscripts at

http://www.hindawi.com
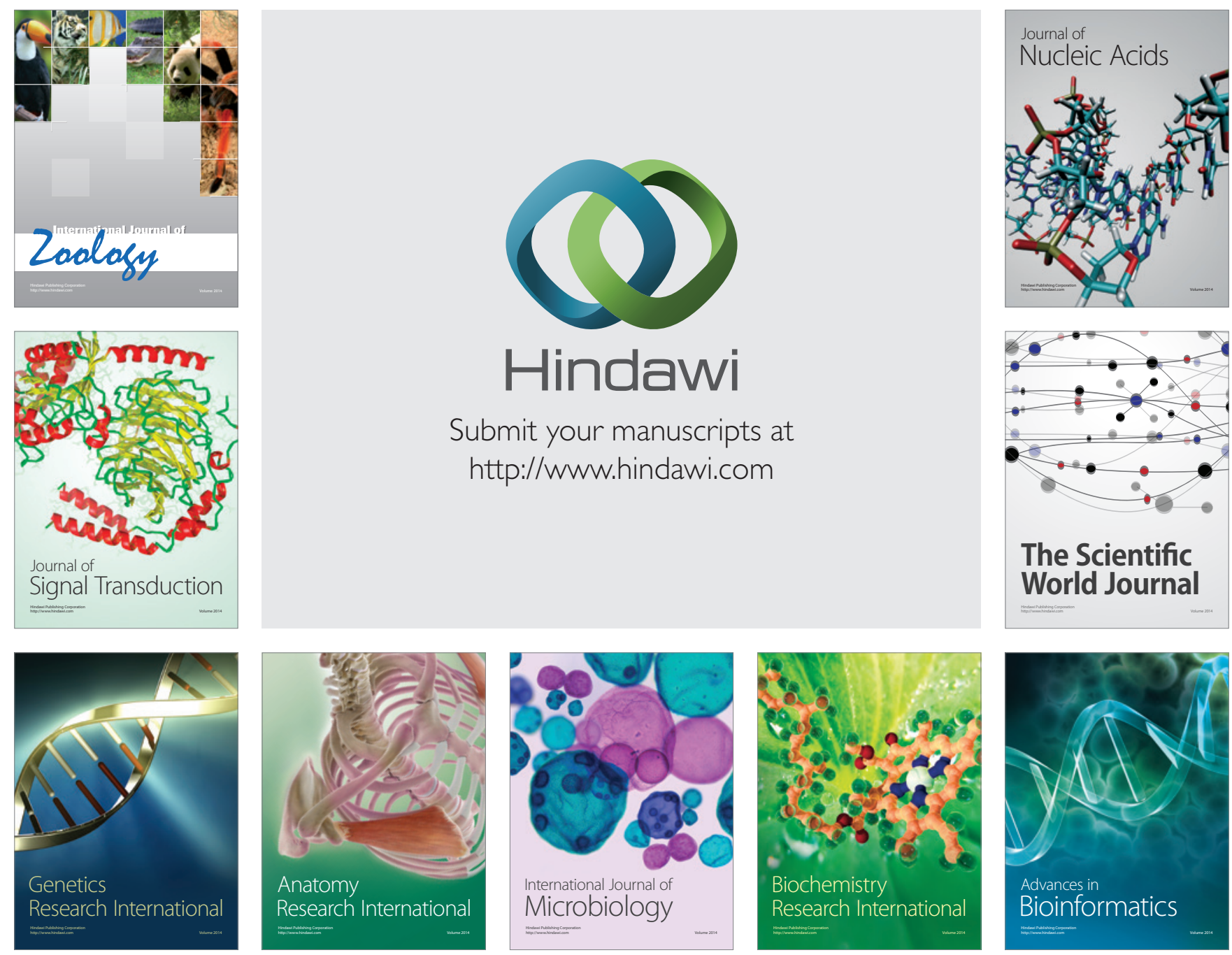

The Scientific World Journal
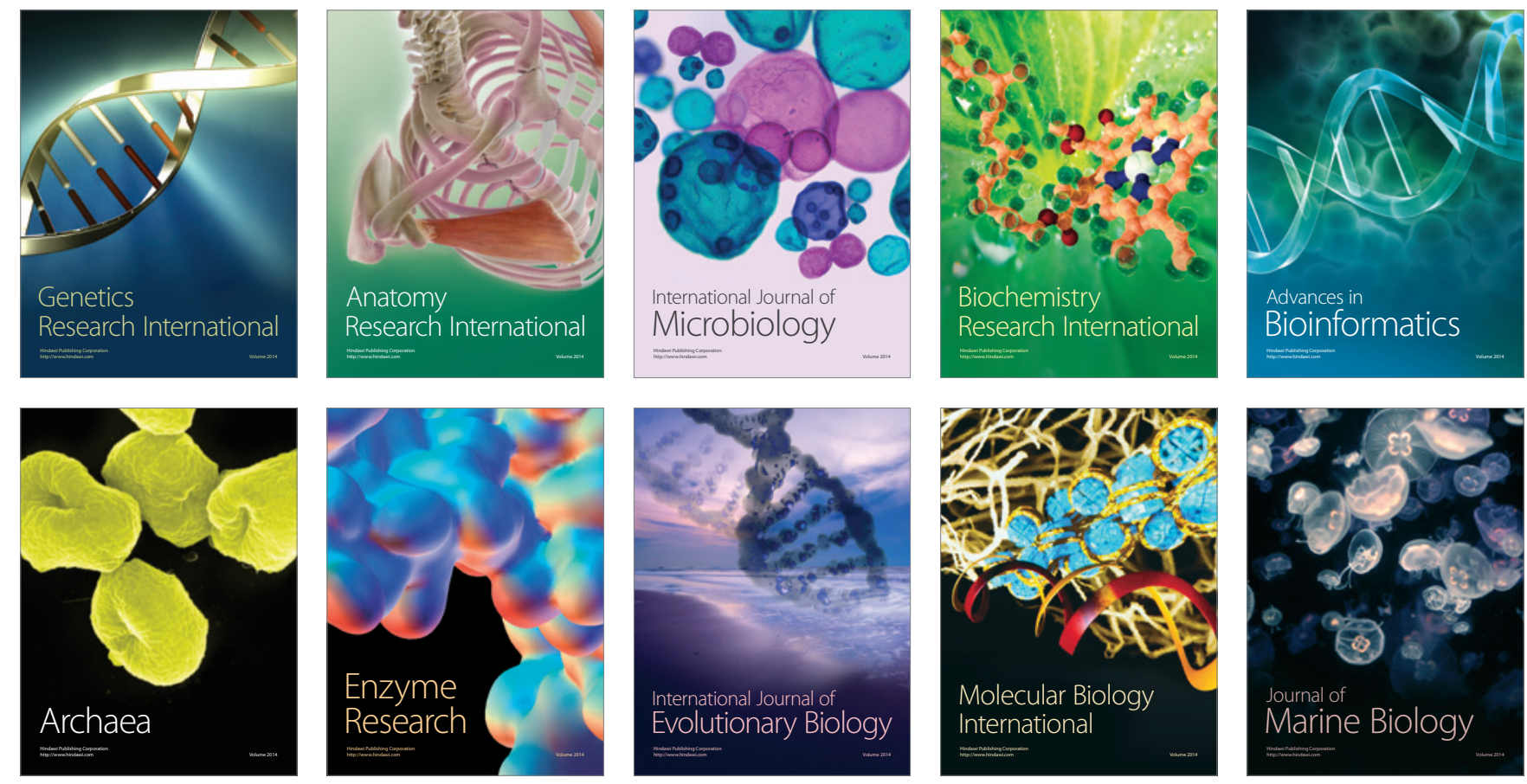